\title{
ЗАПАДНАЯ ЭКСПЕРТНАЯ ОЦЕНКА ВОЗМОЖНОСТЕЙ И ПЕРСПЕКТИВ ВОЕННОГО СОТРУДНИЧЕСТВА С ГОСУДАРСТВАМИ ЦЕНТРАЛЬНОЙ АЗИИ
}

\begin{abstract}
Аннотация. Регион Центральной Азии, в который сейчас принято включать бывшие союзные республики СССР, а ныне независимые государства Казахстан, Узбекистан, Киргизию, Таджикистан и Туркмению , в течение последнего десятилетия XX-начала XXI вв. является одним из наиболее важных изентров сосредоточения геостратегических интересов ведущих мировых держав. В последние годы этот регион все больше привлекает внимание поли-тиков, ученых и военных стратегов. Это обусловлено в первую очередь его геополитическим положением и наличием богатых природных ресурсов, особенно нефти и газа. Туркменистан обладает большими залежами нефти, газа, калийной и каменной соли, цветных и редкоземельных металлов. В Узбекистане находятся крупные месторождения природного газа, бурого и каменного угля, золота, меди, вольфрама, висмута, нефти. В Казахстане имеются большие запасы урана, свинца, ичика, хрома, золота, меди, висмута, молибдена, нефти, фосфоритов, бокситов, железа, марганияа. В Киргизии найдень золото, сурьма, ртуть, уголь, нефть и газ. В Таджикистане сосредоточены месторождения урана, нефти и газа. Большинство стран региона занимают ведущие места в Азии по производству электроэнергии, продукции химической промышленности, металлургии.
\end{abstract}

Ключевые слова: политология, международные отношения, центральная азия, военное сотрудничество, конфликты, НАТО, США, безопасность, нацчиональные интересы, политика.

3 начение региона возросло также в мировой политике в связи с существующей в некоторых государствах региона угрозой прихода к власти исламских фундаменталистов, наличием территориальных споров между странами, ростом наркобизнеса и др.

Сразу после распада СССР интерес США и вообще Запада к Центральной Азии резко возрос именно в связи с запасами углеводородов, которыми обладают некоторые центральноазиатские государства. С другой стороны, в стратегическом мышлении США в отношении Центральной Азии с середины 1990-х гг. доминировал подход, согласно которому только Узбекистан с его большим населением, сравнительно сплоченный этнически, имеющий сравнительно боеспособные вооруженные силы являлся естественным партнером для США в обеспечении стабильности в Центральной Азии и помощи в сдерживании влияния исламских экстремистов ${ }^{1}$. Эта точка зрения подпитывалась также давней озабоченностью Запада относительно попыток России доминировать в «ближнем зарубежье» после распада СССР и тем фактом, что Узбекистан казался единственным из центральноазиатских государств, имеющим необходимые ресурсы и желание противостоять «российским амбициям».

1 См.: S. Frederick Starr, "Making Eurasia Stable," Foreign Affairs, January/February 1996, vol. 75, no.1, pp. 80-92. То, что США должны главным образом опираться на сотрудничество с Узбекистаном, см.: Zbigniew Brzezinski. The Grand Chessboard: American Primacy and its Geostrategic Imperatives, (New York: Basic Books, 1997), pp. 123-150, в частности, где он пишет о «Евразийских Балканах».
После террористических актов 11 сентября 2001 г. и начала 7 октября 2001 г. операции НАТО в Афганистане значение Центральной Азии в стратегическом планировании США и НАТО резко возросло, в частности, в связи с размещением воинских контингентов некоторых стран НАТО на территории ряда центральноазиатских государств.

В феврале 2004 г. американским Институтом анализа внешней политики² был подготовлен документ «Центральная Азия в стратегии и оперативном планировании США», который рассматривал весь комплекс проблем, касающихся обстановки в Централь-

\footnotetext{
2 Институт анализа внешней политики является влиятельной научно-исследовательской организацией в США, которая ассоциируется с известной Флетчеровской школой права и дипломатии и Университетом Тафта. Позиционирует себя как независимая неправительственная аналитическая организация, «помогающая высшим государственным деятелям, руководителям промышленности и должностным лицам, занимающимся государственной политикой, принимать обоснованные решения в современной динамичной и непредсказуемой мировой обстановке». Представляет взгляды правых в американском истэблишменте и наряду с некоторыми другими исследовательскими центрами США (Американский институт предпринимательства, Центр исследований политики безопасности, Институт исследований в области внешней политики, Фонд «Наследие» и Гудзоновский институт) является инструментом произраильского лобби для воздействия на выработку администрацией США соответствующих решений в области внешней политики. -http://en.wikipedia.org/w/index. php?title=Israel_lobby_in_the_United_States\&oldid $=474275304$
} 


\section{Международные отношения International Relations}

ной Азии и путей закрепления Соединенных Штатов в этом регионе ${ }^{3}$.

Он включал общий обзор ситуации в центральноазиатских государствах с точки зрения Вашингтона, прогнозировал развитие событий и давал рекомендации для действий американской администрации по достижению своих военно-политических целей.

Особый интерес представляет видение авторами документа роли и места Российской Федерации в данном регионе, являвшемся когда-то сферой ее влияния, а также предлагаемые методы по вытеснению России из Центральной Азии и занятию ключевых геополитических позиций, обеспечивающих полный контроль над доступом к основным мировым запасам углеводородного сырья, а также дальнейшую изоляцию России.

Документ представляет интерес в первую очередь в связи с тем, что в нем отчетливо просматриваются действительные цели военно-политической стратегии США в Центральной Азии. Он интересен тем, что дает возможность оценить постфактум, какие из заявленных целей и в каком объеме были осуществлены к настоящему времени.

Авторы не скрывали, что главной целью документа является помощь в разработке долгосрочной стратегии по вовлечению США в Центральную Азию. Предполагалось, что это исследование должно было послужить отправной точкой для последующих дискуссий — как внутри правительства, так и в научных кругах и среди специалистов по Центральной Азии из частного сектоpa - по вопросу специфических шагов США с учетом их военного присутствия в регионе и их отношений с центральноазиатскими государствами.

Для этого предлагалось, во-первых, рассматривать этот регион отдельно от Кавказа, а во-вторых, перестать рассматривать запасы углеводородного сырья на Каспии как доминирующий фактор, определяющий политику США в этом регионе мира.

Население Центральной Азии испытывает социальный упадок и экономические трудности, но при этом мало надежд на улучшение в долгосрочной перспективе. По мнению авторов, центральноазиатские правительства сделали основную ставку на репрессивные меры безопасности, контроль и запугивание прессы, ввели президентское правление. Совокупность экономических трудностей и политических репрессий способствует созданию благодатной почвы для экстремистских исламских движений.

Наиболее известными экстремистскими группировками являются «Хизб-ут-Тахрир- аль-Ислами»

\footnotetext{
3 Davis, Jacquelyn \& Sweeney, Michael. Central Asia in U.S. Strategy and Operational Planning: Where Do We Go From Here? // The Institute for Foreign Policy Analysis, Washington DC, 2004 // URL: www.ifpa.org/pdf/S-R-Central-Asia.pdf.
}

(ХТИ) и «Исламское движение Узбекистана» (ИДУ), сосредоточившие свою деятельность преимущественно против режима узбекского президента Ислама Каримова. Это ставило США в неудобное положение, поскольку они поддерживали дружественные отношения со своим главным военным союзником в мусульманском регионе, а этот союзник представлял собой коррумпированный светский авторитарный режим, которому противостояли силы исламских фундаменталистов. Это давало возможность исламскому экстремизму называть США циничным и своекорыстным государством, которое на словах ратует за идеалы демократии, а на деле сохраняет партнерские отношения с авторитарными режимами, поскольку ему нужны военные базы в Центральной Азии.

Авторы документа отмечали в этой связи растущие антиамериканские настроения в регионе и указали на необходимость пересмотра дипломатии США, чтобы привлечь и склонить на свою сторону народы Центральной Азии. Предлагалось усилить закулисное давление США на своих партнеров в Центральной Азии, чтобы осуществить реальные политические и экономические преобразования. Это особенно требовалось в Узбекистане, стране, в которую США инвестировали около половины миллиарда долларов в течение одиннадцати месяцев вслед за развертыванием американских войск на узбекской территории. Своей близостью с режимом Каримова США, по мнению авторов документа, компрометировали себя, поэтому одновременно с нажимом на узбекское руководство с целью проведения либеральных реформ, они предлагали максимально диверсифицировать американское военное присутствие в Центральной Азии. В частности, предлагалось обратить внимание на Казахстан, который представлял собой интересный вариант как альтернативный партнер, так как его экономический и политический потенциал делал его государством Центральной Азии «с наилучшими прогнозами на создание в среднесрочной перспективе нечто близкого к правовому государству» ${ }^{4}$.

При этом масштабное строительство новых военных объектов США в Центральной Азии исключалось. В силу политики сокращения числа американских военных баз предлагалось создавать «передовые операционные базы» (ПОБ) и «передовые операционные пункты» (ПОП). Термин ПОБ предполагает ограниченную, фиксированную инфраструктуру с временно дислоцирующимися войсками. ПОП - это так называемая «горячая точка», занимаемая только периодически.

Рекомендовалось создать по крайней мере одну запасную ПОБ в Казахстане, в одном из трех наиболее

\footnotetext{
4 Davis, Jacquelyn \& Sweeney, Michael. Central Asia in U.S. Strategy and Operational Planning: Where Do We Go From Here? - P. iv.
} 


\section{Региональные конфигурации международных отношений / Regional configuration of international relations}

подходящих аэропортов, где США в настоящее время имеют право на посадку самолетов в экстренных случаях (Алма-Ата, Чимкент или Луговой). Предлагалось также создать в Казахстане еще два объекта в качестве передовых операционных пунктов и изучить возможность создания одного или более ПОП в Таджикистане, учитывая существенную роль Таджикистана в транзите наркотиков через регион.

В то же время авторы документа подчеркивали, что Соединенным Штатам, вероятно, придется сохранить свое присутствие в Центральной Азии на неопределенно долгое время, но при этом нельзя позволить им стать заложником какого-нибудь государства или объекта. В этой связи авторы обращали внимание на нестабильное положение в Пакистане, в руководстве которого далеко не все поддерживали операции США в Афганистане. Базы в Центральной Азии могли бы в определенной степени компенсировать потерю доступа США к объектам на территории Пакистана, если бы там произошел переворот или революция. В то же время, по мнению авторов, существовала необходимость «серьезного изучения» возможности размещения американских войск в Индии, а также дальнейшей разработки концепции морского базирования «ввиду ее применимости для будущих сценариев развития ситуации в Южной Азии и на всем побережье Индийского океана».

В 2004 г. США находились в состоянии трансформации и глобальной перегруппировки сил для адаптации к новым вызовам, брошенным международным терроризмом, наркоторговлей и распространением оружия массового уничтожения (ОМУ $)^{5}$. Сoединенные Штаты планировали постепенное перераспределение своих сил и отход от устаревшей формы противостояния Запада и Востока, чтобы встретить новые угрозы так называемой «дуги нестабильности», простирающейся от Анд в Западном полушарии через Африку южнее Сахары, Ближний Восток, Центральную Азию и заканчивающейся в Юго-Восточной Азии. Окончательный вариант предполагаемой про-

5 В 2000 г. ОКНШ организовал комплексное исследование «Центральной Евразии», предпринятое совместно с Атлантическим советом и Институтом Центральной Азии и Кавказа университета Джона Гопкинса: Charles Fairbanks, C. Richard Nelson, S. Frederick Starr, and Kenneth Weisbrode, Strategic Assessment of Central Eurasia, (Washington, DC: The Atlantic Council of the United States and the Central Asia and Caucasus Institute, January 2001), 131 pp., www.acus.org/Publications/ Default.htm. Затем Сухопутные войска США организовали аналогичное исследование с помощью корпорации РЭНД: Faultlines of Conflict in the Caucasus and Central Asia: Implications for the U.S. Army, Olga Olikar and Thomas Szayna, eds., (Santa Monica, CA: RAND, 2003), 407 pp., www.rand.org/ publications/MR/MR1598/index.html. граммы реорганизации базирования к тому времени был уже подготовлен. Однако некоторые из элементов реорганизации, которые касались, например, планов вывода войск США из демилитаризованной зоны на Корейском полуострове, показывали основные изменения, которые должны были произойти в недалеком будущем ${ }^{6}$. Поэтому базы в Центральной Азии могли бы играть важную роль для перегруппировки ВС США для борьбы с угрозами терроризма и ОМУ не только в самой Центральной Азии, но могли бы стать частью глобальной системы безопасности США.

С этим было связано также то обстоятельство, что произошла переоценка стратегической значимости Центральной Азии как источника энергоресурсов. Это соображение было усилено возросшей очевидностью ограниченности запасов нефти и газа на Каспии. К концу 1990-х годов было опубликовано уже достаточно материалов и статей, которые ставили под вопрос распространенную истину относительно энергозапасов региона7. Мало кто сомневался в том, что Каспийский бассейн может стать значительным источником газа и нефти, но надежды на то, что он устранит глобальную зависимость от источников Персидского залива, ослабли. В центре внимания оказались более реалистичные оценки запасов Каспия и было внесено больше ясности в различие между доказанными и потенциальными запасами региона.

Согласно данным правительства США, потенциальные запасы нефти всего Каспийского бассейна, который поделен между Азербайджаном, Ираном, Казахстаном, Россией, Туркменией и включает западную оконечность Узбекистана, составляют примерно 186 млрд. баррелей при значительно меньших подтвержденных запасах, оценивающихся максимум в 32 млрд. баррелей. Общие запасы (включая потенциальные) составляют приблизительно одну третью часть от подтвержденных запасов Персидского залива, равных 674 млрд. баррелей, прогнозируемый потенциал которых может составить буквально триллионы баррелей. С другой стороны общие потенциальные

\footnotetext{
6 Vernon Loeb, "New Bases Reflect Shift in Military: Smaller Facilities Sought for Quick Strikes," Washington Post, June 9, 2003, p. A01.

7 См., например, Geoffrey Kemp, “The Persian Gulf Remains the Strategic Prize," Survival, vol. 40, no. 4, (Winter 1998-99), pp. 132-149; Martha Brill Olcott, "The Caspian's False Promise," Foreign Policy, no. 111 (Summer 1998), pp. 95-112; Amy Myers Jaffe and Robert Manning, "The Myth of the Caspian 'Great Game': The Real Geopolitics of Energy,” Survival, vol. 40, no. 4, (Winter 1998-99), pp. 112-131; and Amy Myers Jaffe, Unlocking the Assets: Energy and the Future of Central Asia and the Caucasus, (Rice University: James A. Baker, III Institute for Public Policy, April 1998), 26 pp.
} 


\section{Международные отношения International Relations}

и подтвержденные запасы Каспийского бассейна составляют примерно три четверти от подтвержденных запасов одной только Саудовской Аравии (264,2 млрд. баррелей), общие прогнозируемые запасы которой составляют 1 трлн. баррелей. Что касается газа, Каспийский бассейн имеет немногим больше четверти подтвержденных запасов Персидского залива: пять прикаспийских государств с Узбекистаном имеют суммарный подтвержденный и потенциальный запас равный 560 трлн. кубических футов, когда подтвержденные запасы Персидского залива - 1923 трлн. куб. футов $^{8}$. Короче говоря, Каспий можно назвать важным регионом, однако ведущая роль Персидского залива в импорте нефти и газа непоколебима.

Более того, несмотря на усилия США стимулировать участие Казахстана и Туркменистана в западноориентированных трубопроводах (например, Баку-Шейхан) большая часть нефти и газа из этих двух государств поступала и продолжает поступать в Россию и другие бывшие советские государства, а также в меньшей степени в Иран, или используется для внутреннего потребления. И Тегеран, и Москва будут стремиться купить дешевую центральноазиатскую энергию для внутреннего потребления, что позволит им повысить поставки собственных нефти и газа на более прибыльные западные и азиатские рынки. Таким образом, прямое влияние Каспия на мировой энергетический рынок не станет столь же существенным, как, скажем, Венесуэлы ${ }^{9}$. А если будет доказано, что потенциальные запасы этого бассейна явно преувеличены, его влияние на стратегическое планирование США может быть еще меньше.

В то же время в 2004 г. Центральная Азия представляла собой весьма важный для США регион, поскольку с одной стороны, она могла быть возможным прибежищем для террористов, с другой стороны, была необходима для обеспечения антитеррористических операций, в частности, в Северном Афганистане ${ }^{10}$.

Поэтому сначала было важно разделить Кавказ и Центральную Азию в стратегическом планировании США. С одной стороны, это уже произошло после того, как в 1999 г. в зону ответственности Централь-

\footnotetext{
8 Данные взяты из статистических отчетов Управления информации по энергозапасам США - www.eia.doe.gov. См, в частности, Persian Gulf Energy Fact Sheet, April 2003, www. eia.doe.gov/emeu/cabs/pgulf.html, and Caspian Sea: Key Oil and Gas Statistics, August 2003, www.eia.doe.gov/emeu/cabs/caspstats.html.

9 Ibid.

10 George W. Bush, Address to a Joint Session of Congress and the American People, September 20, 2001, the U.S. Capitol, Washington, DC, www.whitehouse.gov/news/releases/2001/09/20010920-8.html.
}

ного командования США наряду с Большим Ближним Востоком были включены центральноазиатские государства, а также Афганистан. Однако необходимо было, чтобы это поняли и в Государственном департаменте США.

Другой важной проблемой, по мнению американских политологов, являлось отсутствие в центральноазиатских государствах гражданского общества. Согласно «Ежегодному исследованию свободы», которое издает «Фридом хаус», только Кыргызстан в 2003 г. оценивался «частично свободным». Туркменистан получил наименьшее число баллов, Узбекистан следовал вплотную за ним. Казахстан и Таджикистан оценивались лучше, но по-прежнему заслуживали твердой оценки «не свободны» ${ }^{11}$.

С точки зрения американских политологов, в 2004 г. ни один из режимов в Центральной Азии не мог быть охарактеризован как идеальный или даже привлекательный партнер. Глава Узбекистана Каримов, основной региональный партнер США после событий 11 сентября, представлял собой наиболее безжалостного и успешного из центральноазиатских диктаторов. Его политика безопасности и упрямый отказ проводить экономические преобразования создавали вполне достаточную мотивацию для сограждан в худшем случае поддерживать экстремистские группы типа «Исламское движение Узбекистана», а в лучшем случае просто выражать протест режиму и соответственно - финансовой и политической поддержке его Соединенными Штатами.

В связи с этим возникла необходимость искать альтернативу Узбекистану, и в качестве такой альтернативы виделся Казахстан «как наиболее приемлемая смесь политических сил и экономических ресурсов, способных достичь уровня квази-свободного государства, даже если его форма, своеобразный вид олигархии, будет далека от модели демократии» ${ }^{12}$. Основной вопрос заключался в том, соответствует ли Казахстан военно-операционным требованиям США, так как этому соответствуют объекты в Узбекистане.

\footnotetext{
11 “Фридом хаус» оценивает каждую страну по двум шкалам, что в свою очередь используется для определения уровня свободы. В первой шкале оцениваются гражданские свободы от 1 (наилучший) до 7 (наихудший). Во второй шкале используются те же самые критерии для оценки политических прав. В частности, полученные оценки для стран Центральной Азии следующие: Казахстан $(6,5)$, Киргизстан $(5,5)$, Таджикистан $(6,6)$, Туркменистан $(7,7)$, и Узбекистан $(7,6)$. Для сравнения, оценка США $(1,1)$. Для получения более полной информации см.: www.freedomhouse.org/ratings/index.htm.

12 Davis, Jacquelyn \& Sweeney, Michael. Central Asia in U.S. Strategy and Operational Planning: Where Do We Go From Here? P. 26-27.
} 


\section{Региональные конфигурации международных отношений / Regional configuration of international relations}

Не менее важная проблема заключалась в том, чтобы завоевать на свою сторону общественное мнение населения Центральной Азии. Выступая в Джорджтаунском университете в октябре 2003 г., заместитель министра обороны Пол Вулфовиц дал один из первых ясных образцов обращения к «войне идей», концепции, которая циркулировала в администрации Буша сразу после 11 сентября 2001 г. Эта концепция абсолютно проста: обычные боевые операции недостаточны для победы над терроризмом. Нужно кроме этого завоевать «сердца и умы» тех, кто поддерживает террористов и в конечном итоге нужно найти путь для снижения привлекательности терроризма для будущих поколений. Вулфовиц сказал: «Частью нашей программы должно стать непосредственное обращение к людям, поскольку на них сосредоточено основное внимание либеральной демократии, и они являются действительным движителем перемен. Соответственно нам нужно более внимательно прислушиваться в голосам умеренных в мусульманском мире. Нам нужно ободрять их и, как сказал президент, «вести мир к тем ценностям, которые принесут длительный мир $»^{13}$. Партнерство США с некоторыми проблемными режимами в Центральной Азии ставило их в неловкое положение. Однако США игнорировали этот стратегический аспект, создавая тем самым себе угрозу.

В своей статье в «Нью-Йоркере» за ноябрь 2001 г. давний исследователь Ближнего Востока Бернар Льюис попытался объяснить источники конфликта между Западом и миром ислама после того, как все еще пребывали в шоке после атак на Центр мировой торговли и Пентагон. Среди многих источников исламской ненависти к Западу, по мнению Льюиса, возможно, наиболее бесспорным является широко распространенное на Ближнем Востоке восприятие Соединенных Штатов как глубоко циничного государства в отношении мусульманского мира. С одной стороны, Америка заявляет о демократии и правах человека, а с другой оказывает помощь тоталитарным режимам в арабском и вообще мусульманском мире, которые угнетают свои народы и не дают им возможности участвовать в правительствах. Заинтересованность США в нефти (и других экономических ресурсах), так же как их требования предоставить им военные базы и соответствующие пути прохода, рассматриваются как основной мотив американского правительства, а громогласные заявления о демократии и правах человека - как пу-

13 Paul Wolfowitz, Winning the Battle of Ideas: Another Front in the War on Terror, Georgetown Iden Lecture, Georgetown University Walsh School of Foreign Service, Washington, DC, October 30, 2003, www.defenselink.mil/speeches/2003/sp20031030depsecdef0642.html. стые слова, что демонстрирует абсолютное лицемерие Америки в глазах многих жителей Ближнего Востока. Еще хуже, как отмечал Льюис, обида многих мусульман и арабов на США за то, что они от них «многого не ожидают». Иначе говоря, существует мнение, что на Западе не считают население Ближнего Востока достойным чего-либо большего, чем те общества, в которых они живут сейчас, хотя это резко контрастирует с теми усилиями, которые предпринимают США для продвижения демократии где бы то ни было ${ }^{14}$.

Как бы отвечая на эту статью, президент Дж. Буш в ноябре 2003 г. выступил с речью на церемонии в честь 20 -летия создания Национального фонда пожертвований в пользу демократии ${ }^{15}$. Он сказал, что отвергает представление о том, что ислам и демократия несовместимы, а затем обратился к Саудовской Аравии и Египту с призывом показать «истинное лидерство» в достижении демократии для народов Ближнего Востока. Хотя Буш воздержался от открытой критики как Каира, так и Эр-Рияда за их недостатки в области демократии, но то, что он публично на таком форуме поднял вопрос о необходимости демократии в Египте и Саудовской Аравии само по себе было важным индикатором необходимости корректировки политики США в отношении Ближнего Востока.

По мнению американских политологов, кроме «войны идей», необходимо применять чисто военные средства в борьбе с терроризмом, наркобизнесом и еще одной ключевой проблемой национальной безопасности США - распространением оружия массового уничтожения. Отслеживание и перехват путей наркоторговли будет приобретать все большее значение в среднесрочной перспективе, помимо нынешних задач по проведению операций по стабилизации и преследованию отдельных лидеров террористических групп. Это по необходимости должно быть включено в оценку требований для будущего военного присутствия США в Центральной Азии и может в конечном итоге затруднять для США возможность полного разрыва военных отношений с центральноазиатскими режимами, даже если другие факторы (например, рост антиамериканизма, сохраняющаяся коррупция) будут делать такой шаг привлекательным.

Общепризнанно, что одним из основных источников финансирования международного терроризма в Центральной Азии являются средства от продажи

14 Bernard Lewis, "The Revolt of Islam," The New Yorker, November 19, 2001, archived online at www.newyorker.com/fact/ content/?011119fa_FACT2.

15 George W. Bush, Remarks by the President at the 20th Anniversary of the National Endowment for Democracy, U.S. Chamber of Commerce, Washington, DC, November 6, 2003, www. ned.org/events/anniversary/oct1603-Bush.html. 


\section{Международные отношения International Relations}

наркотиков. В частности, согласно оценкам, в период своего правления в Афганистане «Талибан» до 80\% от общего дохода получал за счет наркобизнеса ${ }^{16}$. Лидер ИДУ Джума Намангани также использовал прибыль от продажи героина для финансирования деятельности своего движения.

Другими словами, две из трех основных террористических организаций, против которых боролись США в операции «Несгибаемая свобода», - «Талибан» и ИДУ - финансировались главным образом через средства, полученные от торговли наркотиками. Третья - «Аль-Каида» - как многие считают, использует наркосредства для отвода глаз - чтобы обезопасить свои более легитимные источники финансирования.

Исламские экстремисты далеко не одиноки в получении выгод от торговли наркотиками. По мнению американских экспертов, наркоторговля остается важным источником дохода для некоторых правительств региона и важным источником коррупции на всех правительственных уровнях.

В 2004 г. больше всего беспокоило то, что увеличение производства наркотиков и влияние военных действий в Афганистане изменили зоны их производства и пути транзита, увеличив значение центральноазиатских государств в торговле наркотиками. Мак начали активно выращивать в провинции Бадахшан на северо-востоке Афганистана, что соответственно увеличило для наркоторговцев значение транзитных путей через Центральную Азию ${ }^{17}$. Согласно данным 2003 г. Государственного департамента США о производстве опия-сырца в Афганистане, наблюдалась дальнейшая диверсификация районов выращивания мака и увеличение количества лабораторий, перерабатывающих опий в конечный продукт - героин ${ }^{18}$. До этого большая часть афганского урожая мака вывозилась за границу, где перерабатывалась в наркотики.

Иран и Пакистан длительное время были главными путями транзита и сохраняют свою важность в

16 The Threat Posed from the Convergence of Organized Crime, Drug Trafficking, and Terrorism, Testimony by Frank Cilluffo, Deputy Director, Global Organized Crime Program, Center for Strategic and International Studies before the House Judiciary Committee, Subcommittee on Crime, December 13, 2000, www. csis.org/hill/ts001213cilluffo.html.

17 Pierre-Arnoud Chouvy, "Opiate Smuggling Routes from Afghanistan to Europe and Asia," Jane's Intelligence Review, March 2003, p. 28-31.

18 "Chapter VII: Southwest Asia," International Narcotics Strategy Report, U.S. Department of State, Bureau for International Narcotics and Law Enforcement Activities, March 2003, p. 6 . этом плане несмотря на появление возможностей на севере. В Центральной Азии главные пути транзита лежат через Таджикистан. Но Туркменистан также получает выгоду от транзита наркотиков, которые идут в направлении Каспия и далее. В конечном итоге все пять центральноазиатских государств глубоко вовлечены в перевозку наркотиков из Афганистана в Россию и Восточную Европу ${ }^{19}$.

По признанию американских специалистов, в 2004 г. США избегали излишне активной роли в операциях по борьбе с наркотиками в Афганистане. Строительство постталибского стабильного Афганистана требовало длительного времени и у вооруженных сил США были более неотложные задачи, которые нужно было решать, начиная с необходимости полностью устранить «Талибан». В то же время признавалось, что в обозримой перспективе (через год) может быть необходимой стала бы более активная роль в отслеживании и пресечении торговли наркотиками в Центральной и Южной Азии, если США хотят уничтожить основной источник финансирования террористических сетей.

Как отмечалось, еще одна из причин, по которой Соединенным Штатам необходимо использовать свои возможности для борьбы с торговлей наркотиками, состоит в том, что каналы их транзита могут быть непосредственно задействованы для решения других задач терроризма, включая поставки оружия и, прежде всего, оружия массового уничтожения. Поэтому перехват путей наркотрафика несомненно помог бы ограничить и контрабанду оружия.

У западных аналитиков существовали и существуют опасения относительно намеренной передачи биологических и ядерных материалов террористам из соседних с Центральной Азией государств. Пакистан и Иран могут быть потенциальным источником получения ядерного устройства террористами, а пути контрабандного транзита могут быть путями переброски такого оружия. Кроме этого, как полагают, через внутреннюю Азию может пролегать наиболее вероятный маршрут переброски ядерных и ракетных компонентов из Северной Кореи в Пакистан и на Большой Ближний Восток.

Отслеживание этих перебросок потребовало бы усиленного использования средств разведки и наблюдения для слежения за известными путями контрабанды. С учетом этого, как считают американские эксперты, вопрос о том привлекать или не привлекать вооруженные силы США для борьбы с наркотиками должен быть оставлен в области риторики, хотя неко-

\footnotetext{
19 Chouvy, "Opiate Smuggling Routes from Afghanistan to Europe and Asia".
} 


\section{Региональные конфигурации международных отношений / Regional configuration of international relations}

торые ссылаются на не совсем удачный опыт применения вооруженных сил США в борьбе с наркотиками в Латинской Америке.

Одновременно с этим считалось целесообразным активизировать совместные военные учения с вооруженными силами государств Центральной Азии (таких как Киргизстан, Таджикистан, Узбекистан) по борьбе с наркотиками, а также более энергично вовлекать в борьбу с наркотиками союзников по антитеррористической коалиции и международные организации. США должны работать с вооруженными силами центральноазиатских государств, чтобы помочь им в создании профессиональной армии и обеспечить их роль как стабилизирующих сил в регионе. В этой связи приветствовалось расширение участия Казахстана, Киргизстана, Таджикистана и Узбекистана в программе «Международное военное обучение и тренировка» (IMET).

В 2004 г. при определении параметров американского военного присутствия в Центральной Азии, необходимого для решения ряда военных задач, администрации США пришлось столкнуться с необходимостью решить также ряд политических проблем. В первую очередь это была проблема демократизации Узбекистана. На первом этапе сотрудничества США попытались тесно привязать к себе Узбекистан через щедрые финансовые вливания. Согласно данным Госдепа США, в 2002 финансовом году правительство США предоставило помощи Узбекистану всего на сумму около 300 млн. долларов, включая около 78 млн. долларов по программе «Излишки гуманитарных товаров, пожертвованные министерством обороны США в частном порядке» (U.S. Defense Department excess and privately donated humanitarian commodities) ${ }^{20}$. Вашингтон и Ташкент подписали соглашение по экономическому сотрудничеству, которое включало грант в 100 млн. долларов узбекскому правительству и еще кредиты на 50 млн. долларов, переводимые через Экспортно-импортный банк США в Национальный банк Узбекистана ${ }^{21}$. По самым скромным подсчетам, в первые 11 месяцев нового партнерства между США и Узбекистаном США передали безвозмездно или в качестве займа около 450 млн. долларов. Кроме этого, как полагают, старшие официальные лица в узбек-

20 See U.S. Government Assistance to and Cooperative Activities with Eurasia, "Chapter II: Country Assessments - Uzbekistan," Released by the Bureau of European and Eurasian Affairs, U.S. Department of State, January 2003, available at www.state.gov/p/ eur/rls/rpt/23630.htm.

21 Farida Harba, "U.S. Economic Assistance to Greatly Expand under Economic Cooperation Agreement," Eurasianet, December 10, 2001, www.eurasianet.org/departments/business/articles/ eav121001.shtml. ском правительстве хорошо обогатились за счет продажи топлива армии США, даже прекратив на время полеты национальной узбекской авиакомпании, чтобы обеспечить поставки топлива и предотвратить поиск американцами альтернативных источников топлива в регионе 22 .

В марте 2002 г. большая делегация во главе с Каримовым прибыла в Вашингтон, чтобы закрепить новое партнерство. Одним из центральных моментов этого визита стало подписание «Рамочного соглашения о стратегическом партнерстве и сотрудничестве» из пяти пунктов. В документе заявлялось, что США «с большой озабоченностью воспринимают любую внешнюю угрозу безопасности и территориальной целостности Республики Узбекистан». Но он также содержит специфические цели, для достижения которых США и Узбекистан будут работать совместно для «построения сильного и открытого гражданского общества, создания подлинно многопартийной системы и независимых СМИ, укрепления неправительственных структур и улучшения правовой системы» ${ }^{23}$. В администрации президента надеялись, что подписав такие обязательства, у Вашингтона появится инструмент давления на Ташкент с целью проведения подлинных реформ ${ }^{24}$.

Но эти обязательства, как считают американские политологи, остались только на бумаге. На практике Узбекистан продемонстрировал только символические жесты в плане достижения тех благородных целей, которые содержатся в соглашении о стратегическом партнерстве. Было проведено несколько показательных судов над полицейскими, обвиняемыми в злоупотреблениях, а также была разрешена ограниченная международная инспекция некоторых тюрем. В 2003 г. Каримов впервые за 10 лет разрешил открытые собрания членов «Эрк» и «Бирлик». Но, по мнению американских аналитиков, это были отдельные жесты, а не системная попытка осуществить реальные изменения и провести полномасштабную реформу, необходимую для установления правового государства и ухода от прямого президентского правления.

США были крайне заинтересованы в том, чтобы Узбекистан осуществил реальные реформы, и поэто-

22 Sandra I. Erwin, "War on Terrorism Tests Logisticians' Skills," National Defense Magazine, July 2002, www. nationaldefensemagazine.org/article.cfm? $\mathrm{Id}=839$.

23 United States-Uzbekistan Declaration on the Strategic Partnership and Cooperation Framework, U.S. State Department Fact Sheet, March 12, 2002, www.state.gov/r/pa/prs/ ps/2002/8736.htm.

24 Jackson Diehl, "Our Cold War Hangover," The Washington Post, March 18, 2002, p. A17, Lexis-Nexis. 


\section{Международные отношения International Relations}

му им необходимо было наращивать давление на режим Каримова, чтобы он пошел по этому пути. Это помогло бы спасти репутацию США, которая страдала от сотрудничества с Каримовым и вела к росту антиамериканских настроений в мусульманском мире, и сохранить Узбекистан в качестве эффективного и важного партнера в обеспечении долговременной стабильности в Центральной Азии.

С этой целью предлагалось использовать все имеющиеся рычаги давления на узбекское правительство. Во-первых, это был вопрос о финансовых вложениях. Несомненно, часть экономической помощи от США попадала в карманы старших узбекских чиновников и утекала через контролируемые ими каналы. Точно так же, как это было в случае с поставками горючего для армии США, присутствие американских войск на территории Узбекистана создавало другие экономические возможности для узбекских чиновников, обладающих властью и связями. Как считали американские политтехнологи, если бы США вывели свои войска или свернули свое партнерство с Узбекистаном, то узбекские руководители, включая самого Каримова, потеряли бы важный источник личных доходов.

Во-вторых, как считалось, Узбекистан нуждался в американском присутствии в регионе в интересах собственной безопасности, возможно даже больше, чем США - в своих базах в Узбекистане. По мнению американских специалистов, на этой основе и с учетом экономических инструментов и стимулов, имевшихся в распоряжении США, в 2004 г. они имели более благоприятную ситуацию для того, чтобы поднимать вопросы прав человека и политических реформ, которые являются центральными для «войны идей».

Американские эксперты проанализировали базирование вооруженных сил США в Центральной Азии в 2004 г. и возможные альтернативы.

Узбекистан. Являлся главным военным партнером США в Центральной Азии. Соединенные Штаты имели около тысячи военнослужащих на его территории, дислоцирующихся прежде всего на бывшей советской авиабазе Ханабад рядом с городом Карши, а также на аэродроме Тузел в районе Ташкента. Авиабаза Ханабад, называемая также Карши-Ханабад, играла важную роль в операции «Несгибаемая свобода» и использовалась в качестве командного пункта для нанесения воздушных ударов, координации действий сил специальных операций, проведения поисковоспасательных операций в северном Афганистане ${ }^{25}$.

25 Robert Wall, "MH-47 Crews Detail Conflict's Exploits, Woes," Aviation Week \& Space Technology, April 15, 2002, www. aviationnow.com/content/publication/awst/20020415/aw22.htm
Аэродром Тузел, по неподтвержденным официально данным, использовался для обеспечения полетов разведывательных беспилотных летательных аппаратов типа «Предатор» ${ }^{26}$.

Кыргызстан. ВС США имели приблизительно 700 человек на военной базе Манас. Данный объект в основном играл роль центра тылового обеспечения и пункта дозаправки топливом военно-транспортных самолетов ВС США. Кроме того, база принимала небольшие подразделения боевых самолетов стран НАТО, и на ней базировались некоторые подразделения сил коалиции, а также медицинское подразделение Республики Корея ${ }^{27}$. В целом администрация президента Акаева меньше афишировала свои связи с коалиционными силами, чем Каримов, а само присутствие войск США и НАТО в Кыргызстане гораздо менее популярно среди местных жителей, чем в Узбекистане ${ }^{28}$. Тем не менее, присутствие США в Манасе было прибыльным для Кыргызстана, поскольку США, как сообщают, платили 7 тыс. долларов за каждый самолетовылет.

Таджикистан. Формально США не имели здесь никаких сил, но получили право на пролет воздушного пространства Таджикистана. Американские эксперты предполагали, что президент Рахмон несомненно не будет возражать против прямого военного присутствия ВС США на своей территории, если это

26 Численность и дислокация войск даются по: Military Balance 2002-2003, (London: Oxford University Press, October 2002), pp. 127-137. Расположение и предназначение конкретных баз даются по информации с сайта GlobalSecurity. org, который дает подробную открытую информацию по подтвержденным и вероятным объектам, используемым CENTCOM в операциях «Свободу Ираку» и «Несгибаемая свобода», а также в военных операциях США на других ТВД. Информация также была получена с сайта www.centcom.mil. См. также: Kenley Butler. Central Asian Military Bases. Center for Nonproliferation Studies (CNS) at the Monterey Institute of International Studies, cns.miis.edu/research/wtc01/cabases.htm

27 Франция первоначально развернула авиаподразделение из 6 самолетов «Мираж-2000» для непосредственной авиационной поддержки в Афганистане. Впоследствии Дания, Нидерланды и Норвегия перебросили туда по 6 самолетов F-16, при этом происходила их периодическая замена на ротационной основе. Дания и Норвегия прекратили посылать свои самолеты в октябре 2003 г.

28 См.: "Yankees Go Home, Some Kyrgyz Say," in RFE/ RL Central Asia Report, 28 February 2002, vol. 2, no. 8, compiled by Adam Albion, available at www.rferl.org/ centralasia/2002/02/8-280202.asp. В противовес американские наблюдатели приводят «анекдотичные факты» того, как жители Ханабада выказывали искреннюю поддержку войскам США, в частности, из-за того, что их присутствие дало толчок местной экономике. 


\section{Региональные конфигурации международных отношений / Regional configuration of international relations}

будет сопряжено с соответствующей экономической выгодой. В Таджикистане много объектов, представляющих интерес для США, которые можно было бы восстановить при соответствующих финансовых вложениях. При необходимости Соединенные Штаты могли бы финансировать восстановление инфраструктуры и использовать расположенные на юге страны вдоль афганской границы аэродромы Хорог, КурганТюбе, Пархар и Куляб. Последний когда-то был довольно большой советской базой, как сообщается, был обследован Центральным командованием сразу после 11 сентября, но был отвергнут из-за его плохого состояния ${ }^{29}$

На территории Таджикистана в Душанбе также находятся 201-я мотострелковая дивизия ВС России численностью 7800 человек, а также 100 человек французского персонала, развернутого в аэропорту Душанбе для тыловой поддержки французских сил, действующих в Афганистане в рамках международных сил по поддержанию безопасности.

Казахстан. Наиболее удаленное от Афганистана из пяти центральноазиатских государств. Предоставил США права пролета воздушного пространства и доступа на свою территорию для переброски материально-технических средств, однако не имеет мест базирования каких-либо боевых подразделений ВС США.

С учетом его регионального соперничества с Узбекистаном Казахстан попытался изменить эту ситуацию, опасаясь, что тесные связи между Ташкентом и Вашингтоном будут в конечном итоге ему в ущерб и будут подстегивать амбиции Каримова к политической (если не военной) гегемонии Узбекистана в Центральной Азии. К концу 2001 и в 2002 гг. Астана неоднократно выступала за более тесные военные связи с США, чтобы компенсировать наращивание американских войск в Ханабаде. В конце концов США удовлетворили желание Астаны и подписали соглашение, предусматривающее возможность использования коалиционными силами трех аэродромов на юге страны (Чимкент, Луговой и Алма-Ата) для посадки в экстренных случая ${ }^{30}$. Эти три аэродрома расположены на юго-востоке страны вдоль границы с Киргизстаном и Узбекистаном и почти на таком же расстоянии от Афганистана, как Ташкент и Манас.

\footnotetext{
29 Vernon Loeb, "Footprints in Steppes of Central Asia; New Bases Indicate U.S. Presence Will Be Felt after Afghan War,” The Washington Post, February 9, 2002, p. A01, Lexis-Nexis

30 "U.S. to use Kazakh Bases," in RFE/RL Central Asia Report, May 2, 2002, vol. 2, no. 17, compiled by Adam Albion, www. rferl.org/centralasia/2002/05/17-020502.asp
}

Туркменистан. Обладает наиболее стратегически выгодно расположенной бывшей советской авиабазой Мары, но также является единственным центральноазиатским государством, которое приняло политику нейтралитета, время от времени граничащего с изоляционизмом. Туркменистан предоставил США и коалиционным силам права пролета с гуманитарными миссиями, но воздержался от предоставления военной поддержки в любой форме. Эта единственная из пяти центральноазиатских стран не является официальным членом коалиции «Несгибаемая свобода». База Мары идеально расположена с точки зрения военного планирования. От иранской границы ее отделяет 50 миль, а от афганской - менее 100 миль. По мнению американских аналитиков, данная база была бы полезна не только в контексте операций в Афганистане, но дала бы возможность использовать Центральную Азию в качестве «черного хода» для проникновения в Персидский залив. В обозримом будущем, однако, доступ к туркменским объектам не рассматривался ввиду позиции Ниязова и с целью избежать проблем с различными региональными военными группировками. Мары и другие объекты на территории Туркменистана потребовали бы больших и затратных восстановительных работ. Американские эксперты в контексте будущего планирования предлагали хорошо продумать, как будут развиваться события после ухода Ниязова, поскольку «получение доступа к базе в г. Мары было бы чрезвычайно важным, что могло бы повлиять на планирование чрезвычайных обстоятельств в регионах Персидского залива, Центральной и Южной Азии» ${ }^{31}$.

Карши-Ханабад - очень хорошая база, которая идеально подходит для обеспечения действий американских войск и сил коалиции в Северном Афганистане. Мары и Куляб - хорошие альтернативы, но для использования первого нужна радикальная переориентация курса Туркменистана, а второй требует больших восстановительных работ, к тому же обеспечение базы в центре Памира представляет определенные проблемы. Несомненным преимуществом Куляба является то, что он находится на пересечении многих транспортных маршрутов, используемых для транзита наркотиков и ранее использовался как перевалочный пункт сил «Исламского движения Узбекистана». Он также расположен близко к ключевым пунктам в Афганистане, таким как Панджшерская долина. По мнению американских специалистов, проведение исследования возможности хотя бы ограниченного ба-

31 Davis, Jacquelyn \& Sweeney, Michael. Central Asia in U.S. Strategy and Operational Planning: Where Do We Go From Here? P. 53. 


\section{Международные отношения International Relations}

зирования в Кулябе необходимо было также в связи с тем, что значительные части Таджикистана все еще квалифицировались как «неуправляемые».

Американские эксперты также считали, что в случае необходимости ведения больших воздушных операций альтернативные пункты командования и управления могли бы быть созданы на одном из объектов в Казахстане, предназначенных для экстренной посадки, или в каком-либо другом месте Казахстана, Киргизстана или даже Таджикистана.

Предлагалось также изучить возможности трех баз в южном Казахстане, учитывая, что из пяти государств Центральной Азии Казахстан мог бы стать лучшим региональным партнером для США ввиду его сравнительно благоприятных перспектив политических и экономических преобразований. В частности, предполагалось, что передислокация подразделений разведывательных БЛА из района Ташкента в пригороды Чимкента или Алма-Аты могла бы стать первым шагом в укреплении американо-казахских связей и послужить сигналом узбекскому режиму, что США очень серьезно рассматривают вопрос о диверсификации своего военного присутствия в регионе в случае, если политические и экономические преобразования в Узбекистане не будут проводиться. Наконец, закладывая основы для операционного использования южных авиабаз Казахстана, США создавали бы условия для их задействования в операциях по поддержанию стабильности (или борьбы с терроризмом) в Кыргызстане или Таджикистане в случае, если их режимы потерпели бы крах и в этих государствах возникли беспорядки. С американской точки зрения, и Кыргызстан, и Таджикистан оставались наиболее нестабильными государствами в Центральной Азии и могли служить альтернативным местом убежища для террористов в случае дестабилизации там обстановки.

По мнению американских специалистов, среди объектов в Узбекистане не было ни одного такого, который нельзя было бы заменить его в другом месте, поэтому это не должно было ограничивать наращивание давления со стороны США на режим Каримова с целью проведения серьезных экономических и политических реформ. Они полагали, что Карши-Ханабад не является настолько ценным или уникальным, что он должен делать США заложниками режима, который вредит их репутации в регионе и в целом в мусульманском мире. Если США хотели одержать победу в «войне идей», необходимо было оказывать более сильное давление на узбекское правительство по частным каналам. Это должно было сочетаться с растущей ответственной публичной критикой узбекского режима, наподобие той, которую президент Буш высказал в отношении Саудовской Аравии и Египта.
Чтобы предотвратить наиболее резкие перемены в Афганистане, американские эксперты предложили США поставить целью вывод войск из Карши-Ханабада к концу 2005 г.

Вообще-то главным прибежищем террористических сил в Афганистане всегда были районы проживания пуштунских племен на юго-западе страны и в районе г. Гардез, а также в районах вдоль северной границы Пакистана. Именно поэтому для США был важнее доступ к базам Пакистана, чем в Центральной Азии. В 2004 г. это оставалось важным ввиду охоты на Усаму бен Ладена, его заместителя Айяма аль-Завахири и главу «Талибана» муллу Омара. Поэтому важность Центральной Азии в целом оставалась на втором плане, а главную роль играли силы США, базирующиеся в Афганистане и вдоль границы с Пакистаном.

Большие группы боевиков «Талибана» и «Алькаеды» оставались в основном и большей частью открыто в пакистанской провинции Белуджистан ${ }^{32}$. Этот факт подчеркивал важность Южной Азии в деле охоты на лидеров террористов, а также указывал на непрочный характер отношений США с Пакистаном. Это произошло в связи с тем, что несмотря на союзнические отношения с США в борьбе с терроризмом, некоторые граждане Пакистана, региональные руководители и сотрудники печально известной службы межведомственной разведки продолжали активно поддерживать «Талибан».

Развитие ситуации в Пакистане могло пойти по неблагоприятному для США сценарию вплоть до свержения президента Мушаррафа. И даже если ему на смену пришел бы лидер не исламистского, а умеренного толка, преемник Мушаррафа, согласно американским прогнозам, по меньшей мере, был бы вынужден сократить сотрудничество с США.

Но даже в этом случае оставалось много неясного, как будет развиваться ситуация в Пакистане. Неизвестно было, как поведет себя население Пакистана в случае, если покушение на Мушаррафа окажется успешным. Может быть это могло бы стать сигналом для экстремистов, которые всегда лучше организованы, чем их более многочисленные умеренные противники.

Считается, что наиболее радикализованы пуштуны в северных провинциях Пакистана, но они составляют меньшинство. Большинство составляют пенджабцы, которые привержены традиционному исламу, но чрезвычайно озабочены проблемой Кашмира. Это в свою очередь создает проблему для США, если они хотят наладить более тесные отношения с Инди-

\footnotetext{
32 Ahmed Rashid, "Safe Haven for the Taliban," Far Eastern Economic Review, October 16, 2003, pp. 19-21.
} 


\section{Региональные конфигурации международных отношений /}

Regional configuration of international relations

ей как военным партнером в Южной Азии, поскольку возникает угроза, что та часть населения Пакистана, которая сдерживает растущий исламский экстремизм, выйдет из-под американского влияния ${ }^{33}$.

Несмотря на это, по мнению американских специалистов, США должны были укреплять свои военные отношения с Индией ${ }^{34}$. США должны были реалистично взглянуть на перспективы создания баз в северных районах Индии ввиду неустойчивого положения в Пакистане. США могли понадобиться эти базы и материально-техническое обеспечение операций по обеспечению безопасности или уничтожению пакистанского ядерного оружия, что Индия наверняка поддержала бы. В случае неблагоприятного развития ситуации в Пакистане базы в Центральной Азии имели бы ограниченные возможности для борьбы с террористами в районе пакистано-афганской границы. Поэтому возможные альтернативные варианты базирования в Индии требовали серьезного изучения американскими аналитиками.

В идеале, как считали американские специалисты, двойное развертывание сил США и в Пакистане, и в Индии могло бы символизировать важную стабилизирующую роль США в Южной Азии.

Но существовала еще одна проблема: как справиться с напряженностью и раздражением, которые возникали особенно в России и Китае в связи с присутствием США в Центральной Азии. По мнению американских политологов, реальные опасения относительно попыток России доминировать в Центральной Азии преувеличены, и не потому что в некоторых российских кругах нет такого намерения, а скорее потому, что у России просто нет экономических и военных возможностей для гегемонии в Центральной Азии, и такое положение будет сохраняться в обозримом будущем ${ }^{35}$.

Россия, конечно, сохранит важное влияние в регионе, т.к. обладает почти монопольным правом на трубопроводы, идущие из Центральной Азии, а также как важный рынок труда для рабочих-мигрантов из многих центральноазиатских стран. Но у нее нет ресурсов, чтобы доминировать в регионе, как это

33 Обсуждение противоречий между интересами пенджабцев и пуштунов, а также другими силами в сложной обстановке в Пакистане см.: Anatol Lieven, “The Pressures on Pakistan,” Foreign Affairs, January/February 2002, vol. 81, no. 1, p. 106, Lexis-Nexis.

34 См.: Ian Storey, "Indo-U.S. Strategic Ties on the Upswing," Jane's Intelligence Review, March 2003, pp. 40-43.

35 Davis, Jacquelyn \& Sweeney, Michael. Central Asia in U.S. Strategy and Operational Planning: Where Do We Go From Here? // The Institute for Foreign Policy Analysis, Washington DC, 2004 // URL: www.ifpa.org/pdf/S-R-Central-Asia.pdf. - P. 64. было в советскую эру, и США следует учитывать этот фактор.

Администрация Буша молчаливо отреагировала на открытие российской базы в Канте. Точно так же американские аналитики предлагали игнорировать тех, кто пытался бы доказать, что США должны оставаться тесно связанными с Узбекистаном, чтобы противодействовать восстановлению влияния России в Центральной Азии. Аналогично США не должны позволять другим центральноазиатским странам пытаться играть на остатках противостояния периода «холодной войны». Как сообщалось, президент Рахмон разыгрывал «американскую карту» во время переговоров с Москвой по поводу военной базы и финансирования пограничных войск. Американские аналитики предлагали с настороженностью относиться к подобной тактике, если США действительно хотели бы диверсифицировать свои региональные отношения и собирались осуществлять присутствие в Кулябе или другом таджикском населенном пункте.

Что касается Китая, то, по мнению американских политологов, страхи России по поводу возможной китайской экспансии в Сибири и на Дальнем Востоке сильно преувеличены. Неблагоприятный климат в Сибири и на Дальнем Востоке являются сильным препятствием для миграции, не говоря уже о сильном антиимиграционном лобби в России. К тому же, несмотря на свое богатство полезными ископаемыми, привлекательность Востока России как экономической зоны ограничено в сравнении с Центральной Азией, которая имеет не только благоприятный климат, но и гораздо больший рынок сбыта (60 млн. населения против менее 10 млн. в Сибири и на Дальнем Востоке), а также имеет правительства, которые ждут капиталовложений от Китая.

Экспансия интересов и влияния Китая на запад, в Азию, в противоположность продвижению на север, в Сибирь, также берет истоки в китайской истории. Территория, занимаемая сейчас Таджикистаном и Кыргызстаном на протяжении столетий часто подпадала под юрисдикцию Китая, в том числе Ферганская долина. На пике своей экспансии Китай доминировал даже над большими частями Узбекистана и Казахстана. Поэтому «вторжение» Китая в Центральную Азию вряд ли является неожиданным и может считаться уже идущим процессом с учетом роста экономического и политического могущества Китая в 21 веке.

Энергетические проблемы будут также играть известную роль в интересах Китая в Центральной Азии. В декабре 2003 г. Национальная нефтяная компания Китая вошла в долю в партнерстве с российском Газпромом в проект разработки нового месторождения в западном Казахстане стоимостью 


\section{Международные отношения International Relations}

150-200 млн. долларов ${ }^{36}$. Но здесь опять же возникает опасность преувеличения энергетических запасов Центральной Азии. Хотя Пекин в середине 1990-х гг. предложил серию проектов прокладки газовых и нефтепроводов, ни один из этих проектов не сдвинулся с точки зрения его осуществимости. В июне 2003 г. китайский президент Ху Цзиньтао посетил Казахстан в ходе своей первой официальной поездки за рубеж и вопрос о возобновлении проектов трубопроводов стоял в повестке дня его переговоров с президентом Назарбаевым ${ }^{37}$.

Прорывными для экспорта углеводородов в Китай стали его соглашения с Туркменистаном в 20062008 гг,, согласно которым был осуществлен проект газопровода Туркменистан-Китай с пропускной мощностью 40 млрд. куб. м газа в год. Этот объем газа Китай обязался закупать у Туркменистана ежегодно в течение 30 лет $^{38}$. Кроме этого, Китай предоставил Туркменистану заём на 4,1 млрд. долларов для разработки обширного газового месторождения Южный Ёлотан и вложил также средства в несколько основных энергетических и транспортных проектов в Таджикистане ${ }^{39}$.

Другим доминирующим вопросом, который влиял и будет влиять на отношения Китая с центральноазиатскими странами является уйгурский сепаратизм и нестабильность в Синьцзяне. Китай видит в проблеме Синьцзяна неотъемлемую часть более широкого подхода к территориальной целостности китайского государства. Хотя проблема Синьцзяна не такая острая, как проблема Тайваня или Тибета, но он так же важен для китайской элиты, даже больше, поскольку Пекин может предпринять прямые действия, чтобы удержать Синьцзян под своей властью. Китай сделал подавление уйгурского сепаратизма основным вопросом в своих отношениях в области безопасности с соседними Казахстаном и Киргизстаном и даже прибег к беспрецедентному шагу, пригласив киргизские силы в Синьцзян для совместных антитеррористических учений.

36 Peter Wonacott, "China Lines up Oil Deals Far Afield," Wall Street Journal, December 19, 2003, Section A, p. 13, Lexis-Nexis.

37 Antoine Blua, "Kazakhstan: Hu's Visit Highlights China's Growing Interest in Central Asia," RFE/RL Weekday Magazine, June 4, 2003, www.rferl.org/nca/features/2003/06/04062003161258.asp.

38 Годы, которые изменили Центральную Азию. - М.: ЦСПИ, 2009. - С. 191.

39 Central Asia and the Transition In Afghanistan/ A Majority Staff Report prepared for the use of the Committee on Foreign Relations United States Senate. One hundred twelfth Congress, first session. December 19, 2011. P. 4. — http://www.fdsys.gpo.gov
Эти учения прошли в контексте более широких усилий по развитию сотрудничества в области безопасности в ШОС.

Совместные китайско-киргизские учения в Синьцзяне были второй частью учений «Сотрудничество - 2003», которые стали первыми антитеррористическими учениями ШОС. Первая часть, проводившаяся в восточном Казахстане, проходила вслед за командно-штабными учениями, в которых участвовали штабные офицеры от Китая, Казахстана, Киргизстана и России, и которые сопровождались совместными маневрами казахских, киргизских и российских сил, действовавших по сценарию борьбы с террористами (Таджикистан участвовал в качестве наблюдателя). Участие Китая в учениях и вообще стремление Китая направить усилия ШОС на борьбу с терроризмом в регионе свидетельствуют о той степени серьезности, с которой Пекин воспринимает угрозу экстремистов в Центральной Азии. Сценарий части учений в Синьцзяне говорит красноречивее всяких слов: совместный китайско-киргизский удар по террористам, перешедшим китайскую границу и напавших на правительственные учреждения ${ }^{40}$.

Так же как и открытие российской базы в Канте, учения «Сотрудничество — 2003» несомненно были попыткой Китая напомнить региональным государствам и особенно ближайшим соседям, что он остается вовлеченным в региональную безопасность, даже если США в настоящее время являются главной военной державой в Центральной Азии. Пекин уже испытывает тревогу относительно присутствия США в регионе, рассматривая его как часть более широких усилий по окружению и сдерживанию Китая. Если США разместили бы свой военный персонал в Казахстане - одной из двух стран, дающих прибежище уйгурским диссидентам и, кроме того, там, где находятся энергетические интересы Китая ${ }^{41}$ - это мало способствовало бы ослаблению опасений Китая относительно намерений США. Американские аналитики поэтому предлагали попытаться вовлечь Китай в совместное с США региональное планирование мероприятий по борьбе с терроризмом и распространением ОМУ и таким образом сблизить представления

40 Более подробное описание учений ШОС и хороший анализ его влияния см.: Roger N. McDermott and William D. O'Malley, "Countering Terrorism in Central Asia," Jane's Intelligence Review, October 2003, pp. 16-19.

41 Экспортно-импортный банк Китая предоставил 5-миллиардный долларовый кредит государственному Банку развития Казахстана и еще 5 млрд долларов государственной газодобывающей компании «Казмунайгаз». - См.: Central Asia and the Transition In Afghanistan. P. 4. 


\section{Региональные конфигурации международных отношений /}

Regional configuration of international relations

США и Китая относительно будущей стабильности в Центральной Азии.

Решение США о включении Исламского движения Восточного Туркестана в список террористических организаций было важным шагом, чтобы убедить Пекин, что интересы США и Китая в регионе вполне совместимы. Чтобы еще больше уменьшить беспокойство Китая, как полагали американские специалисты, нужно было рассмотреть сотрудничество США с ШОС в некоторых областях, таких как охрана границ и борьба с наркоторговлей. Кроме этого, США следовало бы проявлять осторожность и гибкость, поскольку Китай объявил разгром «сепаратизма» одной из целей ШОСа. Это могло поднять неудобные вопросы для США в связи с Тайванем и относительно того, как далеко США могли бы зайти в сотрудничестве с ШОС. Если США собирались оставаться в Центральной Азии неопределенно долго, было бы также контрпродуктивно просто игнорировать ШОС, поскольку эта организация, возможно, являлась на то момент единственным региональным механизмом, который давал шанс эффективного развития «некоторого уровня сотрудничества» между Россией, Китаем и четырьмя из пяти центральноазиатских государств. ШОС открыла Антитеррористический центр в Ташкенте в 2004 г., и он мог бы стать одним из механизмов, через который США развивали бы «прагматическое сотрудничество» с этой организацией.

Тогда как, с точки зрения американских аналитиков, необходимость ШОС повышалась, роль НАТО в Центральной Азии была неясна. Конечно, в кругах альянса присутствовало желание расширять связи и программы НАТО в этом регионе, что было причиной поездки в Центральную Азию генерального секретаря лорда Робертсона. Кроме этого, все пять государств Центральной Азии являются членами программы «Партнерство ради мира» (Таджикистан последним присоединился к ней в 2002 г.), и НАТО проводила учения по этой программе в Центральной Азии с 1997 г. Решение, принятое в апреле 2003 г., о передаче НАТО руководства операцией коалиционных сил в Афганистане (ISAF) также усилило значение альянса в региональном уравнении безопасности.

Однако в 2004 г., хотя НАТО была заинтересована в Центральной Азии, в регионе присутствовал минимальный интерес к Североатлантическому альянсу. По иронии судьбы это произошло вследствие того, что в некоторых столицах Центральной Азии существовало мнение, что НАТО стоит на втором месте после прямых отношений с США. Например, интерес Узбекистана к сотрудничеству с НАТО и через эту организацию в основном определялся желанием усилить отношения с США. Но когда он установил прямые формальные отношения стратегического партнерства с США, в Ташкенте стало наблюдаться меньше желания развивать военные и дипломатические отношения с НАТО. В некоторой степени это рассматривалось как наносящее ущерб центральному значению отношений с США в области безопасности, а предложения усилить сотрудничество с НАТО воспринимались в Узбекистане как нежелательная замена гораздо более сильным двусторонним отношениям с США ${ }^{42}$.

НАТО, следовательно, ограничена в своих возможностях развивать региональное сотрудничество в Центральной Азии по тому типу, как это происходило в странах Восточной Европе и Балтии, когда они стремились получить членство в альянсе. В Центральной Азии у НАТО нет его главной «приманки»: возможности вступить в альянс. Ни одно из центральноазиатских государств даже близко не отвечает политическим, экономическим и военным требованиям членства в НАТО, если даже предположить, что альянс может рассмотреть их кандидатуры. Без этого стимула, который обычно помогал НАТО формировать и реформировать вооруженные силы в бывших коммунистических странах Центральной и Восточной Европы, у альянса мало рычагов влияния в Центральной Азии, а те возможности, которые имеются, откровенно говоря, легко перебиваются прямой экономической помощью и военным присутствием США. Это ни в коем случае не означает, что НАТО не важна для региональной безопасности, но, по мнению американских экспертов, нужно с осторожностью и разумными ожиданиями подходить к возможностям НАТО в регионе, в сравнении с ее вкладом в других пост-коммунистических странах.

Конечно, необходимо изучить политический фактор - может ли НАТО быть использована для уменьшения озабоченности со стороны России относительно длительного присутствия Запада в Центральной Азии. Даже если центральноазиатские государства сами ограничены в своих возможностях или желаниях сотрудничать с НАТО и через нее, альянс мог бы выступить в качестве важного механизма взаимодействия с Россией в Центральной Азии и координации военной деятельности между российскими и западными вооруженными силами. Через Совет Россия-НАТО, созданный в 2000 г., Россия является полноправным, хотя не фактическим союзником, и может присутствовать на встречах «двадцатки» для обсуждения вопросов, представляющих взаимный интерес. США следовало бы проявлять осторожность в том, насколько далеко они желали

\footnotetext{
42 Интервью, проведенные Институтом анализа внешней политики, Ташкент, июнь 2003 г.
} 


\section{Международные отношения International Relations}

бы зайти в этих отношениях, но совершенно ясно, что возможности НАТО по более активному взаимодействию с Россией в Центральной Азии требуют изучения. В частности, как полагали, было бы полезно рассмотреть НАТО в качестве механизма проведения совместных учений между силами альянса (включая США) и российскими силами, размещенными под эгидой ОДКБ в Канте и Душанбе.

Для того, чтобы изучить, как были реализованы предложения американских экспертов, выдвинутые в 2004 г., представляется целесообразным проанализировать еще один документ - доклад сенатского большинства «Центральная Азия и переходный период в Афганистане», подготовленный для Комитета по международным отношениям Сената США 19 декабря 2011 г. $^{43}$ Этот доклад, как указывается во введении, представляет собой часть идущего исследования вовлеченности США в Афганистан и в более широкий регион. Доклад является попыткой тщательно исследовать связь между формирующейся всесторонней стратегией по Центральной Азии и инициативами США по миру и стабильности в Афганистане и в регионе в целом. Он основан на полевых поездках сенатского большинства Комитета в Таджикистан, Казахстан, Узбекистан и Киргизстан в октябре 2011 г. и на обширных встречах с экспертами и политиками в Вашингтоне.

В докладе предлагается продолжить поддержку развития «национально ориентированных цивилизованных сообществ в Центральной Азии». США следует продолжать продвигать политические и экономические реформы путем бо́льших вложений, где это возможно, в демократию и управление, здравоохранение, экономическую помощь и обучение английскому языку.

Однако к 2010 г. стало ясно, где эти реформы возможны, а где нет, и соответственно этому выстраивались приоритеты в бюджетных расходах США по оказанию гуманитарной и военной помощи государствам Центральной Азии в 2001-2010 финансовых годах (см. приложения 1-5). Совершенно очевидно, что если в 2001-2002 гг. эти приоритеты распространялись в первую очередь на Узбекистан, Таджикистан и Кыргызстан, то в период 2003-2010 гг. произошло резкое снижение гуманитарной и военной помощи этим трем странам (причем Узбекистану объемы помощи год от года стабильно снижались, а Кыргызстану и Таджикистану, начиная с 2007 г., более или менее стабильно росли). В то же время происходил более или менее

43 Central Asia and the Transition In Afghanistan/ A Majority Staff Report prepared for the use of the Committee on Foreign Relations United States Senate. One hundred twelfth Congress, first session. December 19, 2011. — http://www.fdsys.gpo.gov стабильный рост помощи Казахстану, причем в 20072009 гг. произошел резкий скачок - объемы гуманитарной помощи этой стране возросли в 2 раза, а военной - в 3 раза.

В целом, помощь США государствам Центральной Азии относительно невелика, если сравнивать с Афганистаном и Пакистаном. Например, в 2010 финансовом году общая помощь США Центральной Азии, составила менее 3\% (436,24 млн. долларов) расходов США на Афганистан (14,78 млрд. долларов). Соответственно расходы США на Пакистан в 2010 г. составили около 2,5 млрд. долларов (см. приложение 1).

Весь период на стабильно низком уровне оставались все виды помощи США Туркменистану, и только в 2010 г. наблюдался определенный рост. Интересно также отметить, что за 10 лет общие бюджетные расходы на военную помощь Казахстану составили 74\% от предоставленной ему гуманитарной помощи, Киргизстану - 34\%, Таджикистану - 26\%, Туркменистану — 34\%, Узбекистану — 50\% (см. приложение 16). При этом совершенно четко вырисовывается тенденция: с 2007 г. наблюдается резкий рост (почти до $90 \%$ объемов военной помощи Казахстану относительно предоставленной ему гуманитарной помощи (см. приложение 5).

Это свидетельствует о том, что установки документа 2004 года в общем были реализованы: США свернули свои отношения с Узбекистаном и сделали ставку на Казахстан. Как отмечается в докладе сенатского большинства, следует также отдать приоритет и увеличить помощь Таджикистану и Кыргызстану с учетом нестабильной обстановки там и их важности для региональной стабильности. Тем не менее, в докладе подчеркивается исключительная важность Северной сети доставки (Northern Distribution Network - NDN), которая служит для перевозки нелетальных грузов из Европы для войск США и коалиции в Афганистане через Россию, Кавказ и Центральную Азию. Северная сеть является чрезвычайно важной для обеспечения коалиционных операций в Афганистане и требует поддержки от таких стран, как Узбекистан. Около 75 \% наземных перевозок осуществляется через Северную сеть. Согласно данным Транспортного командования США примерно 40\% все грузоперевозок проходит через Северную сеть, $31 \%$ доставляется по воздуху, а оставшиеся 29\% идут через Пакистан ${ }^{44}$.

Северная сеть включает три наземных маршрута: первый — от порта Поти (Грузия) через Баку, Каспийское море в Центральную Азию; второй - из Риги через Россию, Казахстан и Узбекистан; третий - из

44 Central Asia and the Transition In Afghanistan. P. 5. 


\section{Региональные конфигурации международных отношений /}

Regional configuration of international relations

Латвии через Россию, Казахстан, Кыргызстан, Таджикистан в Афганистан. До 70 \% грузов, идущих по Северной сети, проходит через Хайратонские ворота в Узбекистане.

Северная сеть позволила США диверсифицировать свои пути доставки грузов в Афганистан и не полагаться в этом только на Пакистан. Если в 2009 г. около 90\% невоенных грузов доставлялось в Афганистан через пакистанский порт Карачи, то сегодня больше нелетальных грузов перевозится в Афганистан через Северную сеть, а не через Пакистан.

В Кыргызстане США используют перевалочную базу Манас (Manas Transit Center) в качестве главного центра воздушных перебросок для операций в Афганистане. Манас является пунктом, выполняющим очень важную задачу перевозки грузов туда и обратно практически для всех коалиционных сил в Афганистане. Поддержание этого центра требует активного дипломатического и политического взаимодействия с руководством Кыргызстана.

Конечно, не все произошло точно так, как это прогнозировали американские политтехнологи. Вооруженный мятеж, организованный членами подпольной группировки «Акромийя» в 2005 г. в Андижане, который, по некоторым данным, поддержали США, вызвал охлаждение в отношениях между Узбекистаном и США и американцам пришлось покинуть базу «Карши» в Ханабаде раньше, чем это планировалось ${ }^{45}$. Ташкент обвинил страны Запада в причастности к андижанским событиям. Кроме того, как считают некоторые российские эксперты, развитие ситуации в Узбекистане пошло абсолютно в противоположном направлении от того, которое прогнозировали американские политологи. Не США разорвали отношения с Каримовым, опасаясь, что он дискредитируют Америку в исламском мире, а, наоборот, Каримов, возможно, посчитал, что его тесное сотрудничество с США будет содействовать мобилизации поддержки населения его противниками из лагеря радикальных исламистов ${ }^{46}$.

Нормализация отношений Узбекистана с США и ЕС началась лишь в 2008 году, а спустя год обрела законченные формы. Запад в полной мере восстановил сотрудничество с Ташкентом. Главной причиной изменения позиции Запада стала заинтересованность в использовании транспортно-коммуникационных

45 Итоги десятилетия. В странах СНГ. Андижанский мятеж. Запад признал правоту властей Узбекистана // НГ-Сценарии. 2011. 25 янв. — http://www.ng.ru/scenario/2011-01-25/13_ andijan.html; Опубликованы показания участника андижанских событий // Агентство Uznews.net - http://www.info-tses. $\mathrm{kz} / \mathrm{red} /$ article.php? article $=15460$

46 Годы, которые изменили Центральную Азию. С. 280. возможностей Узбекистана для снабжения войск натовской коалиции в Афганистане. Отмена санкций в отношении Узбекистана, по мнению ряда экспертов, стала своего рода признанием Запада в том, что официальный Ташкент имел право на подавление исламистского мятежа в Андижане ${ }^{47}$. По-видимому, это также означало крах курса в отношении Узбекистана, обозначенного в 2004 г. как «война идей». После того, как в октябре 2010 г. министры иностранных дел ЕС единодушно проголосовали за отмену последней из наложенных санкций (на поставку вооружений), стало ясно, что возобновление контактов на высшем уровне - вопрос времени. В январе 2011 г. состоялся не афишируемый широко визит Каримова в Брюссель, где он провел переговоры с главой Еврокомиссии Жозе Мануэлем Баррозу и генсеком НАТО Андерсом Фогом Расмуссеном.

По мнению американских конгрессменов, за последние годы режим Каримова достиг некоторого прогресса, разрешив, например, Международному комитету Красного Креста посещать тюрьмы. К несчастью, эти шаги затмеваются значительными нарушениями в области прав человека, включая пытки в местах предварительного задержания, заключение в тюрьму защитников прав человека, принудительный детский труд на хлопковых полях и правительственные ограничения в области свободы религии. Тем не менее, как полагают, в интересах США в полном масштабе взаимодействовать с такими авторитарными режимами в рамках двусторонних обязательств, включая безопасность, госслужбу, права человека, торговлю и инвестиции. Об этом же свидетельствует тенденция в относительных объемах военной и гуманитарной помощи, предоставленной Ташкенту: несмотря на общее снижение этих объемов, с 2008 г. относительный объем военной помощи резко вырос и составлял не менее $70 \%$ от гуманитарной (см. приложение 5 ).

Вашингтону не удалось осуществить также «упреждающее реагирование, если представится соответствующая возможность в Туркменистане», т.е. в случае ухода С. Ниязова. США не удалось предотвратить нежелательное развитие событий и приход к власти молодого диктатора, которым стал Г. Бердымухаммедов. Поэтому получение контроля над базой в г. Мары для американских военных отодвинулось на неопределенный срок, что, впрочем, отражается и на бюджетных расходах США на помощь этой стране. То, что в последние годы наблюдался относительный рост американской помощи Туркменистану может свидетельствовать только о том, что наметились по-

\footnotetext{
47 Итоги десятилетия. В странах СНГ. Андижанский мятеж. Запад признал правоту властей Узбекистана.
} 


\section{Международные отношения International Relations}

ложительные сдвиги в развитии этой страны, которые США стремились как-то поддержать, чтобы затем использовать ситуацию в собственных интересах. Однако этот тренд весьма неустойчивый и может быстро угаснуть ${ }^{48}$.

Ставилась задача использовать национальные ресурсы для пресечения торговли наркотиками в Центральной и Южной Азии. В 2004 г. США избегали излишне активной роли в операциях по борьбе с наркотиками в Афганистане, хотя предлагалось в обозримой перспективе (через год) взять на себя более активную роль в отслеживании и пресечении торговли наркотиками в Центральной и Южной Азии, если США хотят уничтожить основной источник финансирования террористических сетей.

Определенные результаты сейчас есть. В 2010 г. производство опиума в Афганистане сократилось на $50 \%$, согласно данным Отдела ООН по наркотикам и преступлениям (United Nations Office on Drugs and Crime - UNODC), но цены на наркотики остались высокими. Это позволило «Талибану» и другим криминальным структурам использовать запасы прежних урожаев, чтобы сохранить высокую прибыльность. Наркотики стали источником дохода для повстанческих групп, при этом «Талибан» получает десятки и возможно сотни миллионов долларов ежегодно от наркоторговли ${ }^{49}$.

Согласно оценке МВД Таджикистана, они перехватывают около 70-80\% всех наркотиков, которые проходят ежегодно через Таджикистан, при этом только 10\% наркотиков, произведенных в Афганистане, идут через Центральную Азию. Однако согласно оценке Отдела ООН по борьбе с наркотиками и преступлениями, 25-30\% наркотиков, произведенных в Афганистане, переправляется через Центральную Азию. По официальным данным США, 30\% наркотиков поступает в Россию из Афганистана через Центральную Азию, в основном через Таджикистан. Эксперты оценивают, что примерно только 5-10 \% этого транзита перехватывается ${ }^{50}$.

В июне 2011 г. Государственный департамент выступил с новой инициативой, предусматривающей расходы в размере в 4,1 млн. долларов, известной как «Инициатива по борьбе с наркотиками в Центральной Азии» (Central Asia Counternarcotics Initiative CACI). Эта инициатива направлена на создание местных возможностей и стимулирование регионального сотрудничества по борьбе с наркотиками. Эта инициатива направлена на создание надежных подразделе-

48 Годы, которые изменили Центральную Азию. С. 206-207.

49 Central Asia and the Transition In Afghanistan. P. 11.

50 Central Asia and the Transition In Afghanistan. P. 4, 13. ний и оперативных групп по борьбе с наркотиками в пяти центральноазиатских государствах, объединяя их с уже существующими оперативным и группами в России и Афганистане. Предполагается наращивание масштабов трансграничных операций между центральноазиатскими и афганскими правоохранительными и военными структурами, включая совместные учения.

Хотя среди местных органов, занимающихся борьбой с наркоторговлей, существует потребность в подобной инициативе, однако остаются серьезные проблемы. Региональное сотрудничество имеет непростую историю в этой части мира. Центральная Азия изобилует региональными организациями и инициативами, многие из которых не смогли достичь заявленных целей. Широко распространена коррупция, и перспектива для благонадежных подразделений остается неясной с учетом недостатка политической воли в нескольких центральноазиатских государствах.

Чтобы быть успешной инициатива по борьбе с наркотиками нуждается в координации по всему кругу внутриведомственных и внутриправительственных инициатив. В 2010 финансовом году США оценочно затратили 69 млн. долларов на борьбу с наркотиками в Центральной Азии через различные программы помощи в области безопасности по линии Министерства обороны и Государственного департамента. Международное сообщество и региональные организации также вложили значительные средства в борьбу с наркотиками и развернули несколько инициатив, включая «Стратегию радуги» Отдела ООН по наркотикам и преступлениям, Проект по борьбе с наркотиками Совета Россия-НАТО, а также различные инициативы по линии ШОС и ОДКБ ${ }^{51}$.

Кроме этого предлагается инвестировать средства в неформальные рабочие группы, такие как Рабочая группа по Северному маршруту (Northern Route Working Group - NRWG). Цель - улучшение обмена информацией и координация совместных операций, а также региональных и международных усилий по борьбе с наркотиками. Рабочая группа по Северному маршруту была создана в 2010 г. для координации совместной борьбы с наркотиками в Северном Афганистане. Она включает службы наркоконтроля России, Таджикистана и Киргизстана, а также представительства Управления по борьбе с наркотиками США в Душанбе, Кабуле и Москве.

Очень остро стоит вопрос об улучшении пограничной охраны. Особенно плохо охраняется таджикоафганская граница. В целом, задача, которую ставили в 2004 г. не привела к желаемому результату. Не уда-

51 Central Asia and the Transition In Afghanistan. P. 12. 


\section{Региональные конфигурации международных отношений / Regional configuration of international relations}

лось наладить полноценное взаимодействие американских специалистов с региональными военными, хотя были вложены определенные средства в сооружение или восстановление пограничных сооружений, обучение таджикских и афганских пограничников в училище в Хороге и осуществление программы по реформе полиции. Количество американских сотрудников по борьбе с наркотиками было сокращено до минимума. Сейчас предлагается в этой связи улучшить взаимодействие с афганской пограничной охраной, обеспечение таджикских пограничников и увеличить штат сотрудников Управления по борьбе с наркотиками США по Центральной Азии ${ }^{52}$.

В 2004 г. ставилась задача по линии официальной дипломатии США включить Центральную Азию прямо в заявления о демократизации мусульманского мира. При этом приветствовались публичные призывы к ключевым странам Ближнего Востока, включая признанных партеров США - Египет и Саудовскую Аравию - проводить «подлинные демократические реформы». С 2005 г. началась переориентации усилий американской политики на государства Ближнего Востока. Главная цель - под флагом «демократизации» авторитарных режимов арабских государств обеспечить беспрепятственный доступ к ближневосточной нефти и дальнейшую изоляцию Ирана. На этом фоне призывы «образца» 2004 года о «демократизации» государств Центральной Азии отошли на второй план, но не утратили свою актуальность.

В настоящее время приоритетным для США считается поддержка «демократического процесса» в Кыргызстане, чтобы обеспечить операции через транзитный центр Манас. Содержание транзитного центра Манас является непростой задачей. В 2006 г. Кыргызстан потребовал значительного увеличения оплаты за его использование. Вопрос был урегулирован к концу года, включая объявленную США сумму в 150 млн. долларов в качестве общей помощи и компенсации. В 2009 г. тогдашний президент Кыргызстана Курманбек Бакиев объявил о своем намерении закрыть транзитный центр большей частью из-за давления со стороны России, которая, как сообщалось, предлагала Бакиеву займы и кредиты для стабилизации бюджета. В 2009 г. США заключили 5-летнее соглашение с Кыргызстаном, повысив ежегодную арендную плату с 17,4 млн. до 60 млн. долларов. Однако подозрительное отношение в Кыргызстане к присутствию США в Манасе пустило глубокие корни, и вопрос о транзитном центре часто выносится на общественное обсуждение ${ }^{53}$.

\footnotetext{
52 Central Asia and the Transition In Afghanistan. P. 13

53 Central Asia and the Transition In Afghanistan. P. 6.
}

Кроме этого, США намерены также вкладывать больше денег в Таджикистан как наименее стабильное государство, но скорее из стратегических соображений сохранить, а, возможно, и усилить свое военное присутствие на Памире. Для укрепления региональной стабильности предлагается развивать ряд трансграничных проектов с Афганистаном в области энергетики («Памир Энерджи»), охраны границы, здравоохранения, профессионально-технического и сельскохозяйственного образования, молодежного движения. В частности, признается высокая эффективность летних лагерей американского типа для молодежи из Афганистана и Центральной Азии аналогичных успешной модели «Саmp America» в Исфаре и Раште в Таджикистане. Программа пребывания включала спорт, обучение английскому языку, курсы руководителей, курсы критического мышления и создания команды, при этом, как полагают американские специалисты, «главное внимание должно уделяться борьбе с причинами терроризма, прежде чем он охватит регионы, уязвимые для экстремизма» ${ }^{54}$.

В настоящее время сохраняется курс на максимальное взаимодействие США с Россией и Китаем в Центральной Азии. Россия, Китай, Иран и Европейский Союз - все разделяют американскую озабоченность относительно наркоторговли, что создает потенциал для лучшего сотрудничества и координации усилий. В то же время американские конгрессмены проявляют беспокойство тем, что Россия и Китай сохраняют сильное присутствие в Центральной Азии. Россия пытается расширять свое влияние через сеть военных баз, торговые соглашения и новые политические союзы, а также может возобновить охрану таджико-афганской границы, если США будут уходить из Афганистана. Китай, в частности, консолидирует свое экономическое и политическое влияние в Центральной Азии путем предоставления кредитов, финансовых вложений и проектов по совершенствованию инфраструктуры. Иран, Южная Корея, Индия, Япония и Турция также играют все большую роль в Центральной Азии.

Наконец, в 2004 г. ставилась задача сделать Индию долгосрочным партнером в Центральной и Южной Азии и продолжить углубление сотрудничества США с Индией в области безопасности, включая создание передовых операционных пунктов (ПОП) как резервного варианта на случай утраты баз в Пакистане.

За последние годы американо-индийские связи получили значительное развитие. В июле 2005 г. президент США Дж. Буш и премьер-министр Индии Манмохан Сингх сделали совместное заявле-

54 Central Asia and the Transition in Afghanistan. P. 9. 


\section{Международные отношения International Relations}

ние, которое предусматривало кроме всего прочего возможность предоставления Индии доступа к ядерным технологиям и расщепляющимся материалам США. Администрация Буша рассматривала это в качестве свидетельства новых стратегических партнерских отношений между Вашингтоном и Нью-Дели ${ }^{55}$. В 2007-2008 гг. был заключен ряд успешных сделок по продаже Индии американского оружия ${ }^{56}$. Президент Барак Обама во время своего визита в Индию в 2010 г. в продолжение политики прежней администрации США заявил о намерении поддержать поэтапное включение Индии в многосторонние режимы экспортного контроля за распространением ядерного оружия $^{57}$.

США приложили немало усилий, чтобы убедить Группу поставщиков ядерного оборудования ${ }^{58}$ предоставить Индии льготный статус, несмотря на ее отказ присоединиться к Договору о нераспространении ядерного оружия. В результате этого было заключено соглашение, которое позволило Индии импортировать достаточное количество урана из Казахстана и других стран, чтобы выработать в 2010 г. ядерной энергии на $40 \%$ больше, чем в предыдущем году ${ }^{59}$. Тем не менее, углубить сотрудничество с Индией до такой степени, чтобы разместить свои базы на ее территории, Вашингтону пока не удалось.

В июле 2011 г. госсекретарь США Хиллари Клинтон объявила об инициативе «Новый Шелковый путь» - долгосрочной экономической концепции превращения Афганистана в транспортный и торговый узел, объединяющий рынки в Индии, Пакистане, Афганистане и Центральной Азии. В числе предлагаемых проектов завершение Афганской кольцевой дороги; установление ж/д сообщения между Афганистаном и Пакистаном; завершение строительства трубопровода Туркменистан-АфганистанПакистан-Индия (TAPI); создание регионального

\footnotetext{
55 Mohammed Arshad. Top U.S. diplomat Nicholas Burns to retire. Reuters. 2008. Jan. 18; Pakistan's Nuclear Future: Worries Beyond War / Ed. Henry D. Sokolski. Strategic Studies Institute, U.S. Army War College. January, 2008. P. 167-218.

56 Analysis: U.S. Aims to Edge Out Russia in Big Arms Sales to India. Reuters, Washington. 2007. Dec. 26, http://www.defensenews.com/story.php?F=3271166\&C=america

57 United States and India. A Shared Strategic Future / Council on Foreign Relations. Aspen Institute India. Joint Study Group Report. Washington: Council on Foreign Relations, September, 2011. P. 4.

58 Организация стран, координирующих экспорт ядерного оборудования и технологий с Международным агентством по атомной энергии.

59 United States and India. A Shared Strategic Future. P. 9.
}

энергетического рынка путем строительства линии электропередачи между Центральной и Южной Азией (CASA-1000) ${ }^{60}$.

В то же время признается, что проблема соединения Центральной и Южной Азии через Афганистан трудноразрешима в свете препятствий для континентального транспорта и торговли, включая недостаточность регионального сотрудничества.

В осуществлении концепции «Нового Шелкового пути» остается много вопросов в том числе подключение к этой программе союзников США - Японии, Южной Кореи и Индии. Основной целью США ставят подключение к решению проблем региона частного сектора и местных правительств, которые должны играть свою роль, запуская своего рода макроэкономические реформы, которые нужны для региональной интеграции. США и другие партнеры могут помочь здесь посредством программ, направленных на рост местных возможностей, и за счет технической помощи. Самое главное, по мнению американских конгрессменов, исключить большие финансовые расходы о стороны США и одновременно расширить политическую поддержку долгосрочного взаимодействия с США, избегая при этом возложения на США невыполнимых ожиданий. На тактическом уровне, например, США могли бы ускорить осуществление нескольких «демонстрационных проектов», таких как использование их мобилизующих возможностей, чтобы собрать всех заинтересованных участников и открыть транспортный коридор между Центральной Азией и портом Гвадар в Пакистане. Одной из первостепенных задач также ставится организация изучения английского языка в Центральной Азии в том числе с помощью волонтеров из пресловутого «Корпуса мира».

В целом, завершая анализ концептуальных взглядов американских экспертов на проблемы Центральной Азии, следует сказать следующее. Первоначальная ставка американских стратегов на блок государств, объединенных в ГУУАМ, потерпела крах, вследствие чего последовал пересмотр американских подходов к региону Центральной Азии, который стал рассматриваться отдельно от Кавказа.

По истечении времени стали понятны истинные цели корректировки американской дипломатии, которые привели к «цветным революциям» на Ближнем Востоке, свержению М. Каддафи в Ливии и попыткам свергнуть Б.Асада в Сирии. При этом режим военных в Египте не подвергался ни малейшему осуждению точно так же, как и автократический режим в Саудовской Аравии. И если Льюис писал об абсолютном лицемерии Америки в глазах мусульманского мира,

60 Central Asia and the Transition in Afghanistan. P. 9. 


\section{Региональные конфигурации международных отношений / Regional configuration of international relations}

то теперь можно говорить об абсолютном лицемерии Америки в квадрате: если раньше речь шла только о громогласных заявлениях в пользу демократии на всем Ближнем Востоке, то теперь эти заявления делаются выборочно с точки зрения стратегических военных планов США, направленных против Ирана. И здесь выбор будет делаться в пользу Египта, управляемого военной хунтой и происламистским парламентом, а не в пользу Сирии под управлением светского просвещенного руководителя.

Большая игра в этом плане ведется и в отношении Центральной Азии. Американские специалисты прямо отмечали, что «существует мало возможностей для США на пути использования и поддержки действенной оппозиции в регионе. Сейчас Соединенные Штаты делают упор на простое культивирование массового гражданского общества в государствах подобных Узбекистану. Это показывает, как далеко мы от жизнеспособных, национально ориентированных политических движений, с которыми можно было бы работать против существующих режимов в большинстве центральноазиатских стран» ${ }^{61}$. Однако одновременно делается далеко идущий вывод, что диверсификация присутствия США в государствах Центральной Азии повышает оперативную и дипломатическую гибкость США, одновременно позволяя иметь бо́льшие возможности для стимулирования конструктивных перемен в таких режимах, как в Узбекистане.

Американские аналитики откровенно признают, что, диверсифицируя свои военные отношения, США могли бы также приглушить видимость своего присутствия. Следует поэтому избегать стационарных баз, даже небольших, потому что они служат конкретным доказательством приверженности США к определенным региональным государствам и выступают в качестве громоотвода для недовольства тех, кто против сотрудничества США с данным правительством.

Но даже при условии диверсификации и возможного сокращения военного присутствия США в Центральной Азии, американские аналитики однозначно делают вывод, что Соединенные Штаты должны оставаться вовлеченными в этот регион мира на длительный срок.

Ассигнования США на помощь Афганистану, Пакистану и Центральной Азии в 2001-2010 гг.

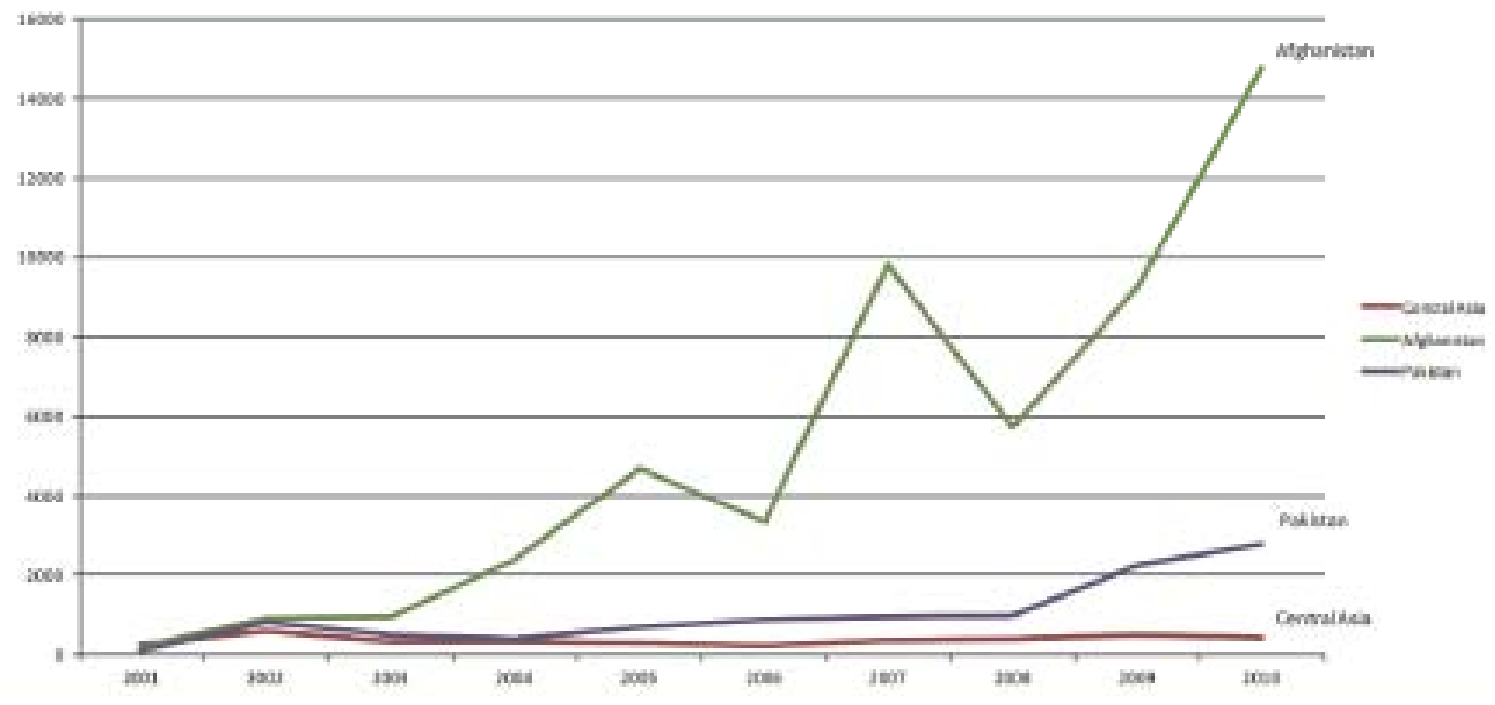

Источник: Central Asia and the Transition In Afghanistan/ A Majority Staff Report prepared for the use of the Committee on Foreign Relations United States Senate. One hundred twelfth Congress, first session. December 19, 2011. P. 20.

По Афганистану, 2002-2010 финансовые года, см.: Curt Tarnoff, "Afghanistan: U.S.Foreign Assistance," Congressional Research Service, R40699, August 19, 2011, р. 16. По Афганистану, 2001 финансовый год, см.: Kenneth Katzman, “Afghanistan: Post-Taliban Governance, Security, and U.S. Policy,” Congressional Research Service,

61 Davis, Jacquelyn \& Sweeney, Michael. Central Asia in U.S. Strategy and Operational Planning: Where Do We Go From Here? P. 27. 


\section{Международные отношения International Relations}

November 22, 2011, RL30588, p. 75. По Пакистану см.: Susan B. Epstein and K. Alan Kronstadt, "Pakistan: U.S. Foreign Assistance," Congressional Research Service, R41856, November 4, 2011, pp. 20-21. Данные по общим бюджетным ассигнованиям на помощь Центральной Азии подготовлены в Исследовательской службе Конгресса США Джимом Найколом, специалистом по России и Евразии, специально для доклада сенатского большинства Комитету по иностранным делам Сената Конгресса США.

Примечания: оценки по Афганистану включают бюджетные программы помощи 050 и 150 за 2001-2010 финансовые годы. Оценки по Пакистану включают общие ассигнования на помощь в области экономики и безопасности за исключением затрат на нужды коалиционных сил, 2001-2010 финансовые годы. Оценки по Центральной Азии включают ассигнования на помощь по данным всех соответствующих организаций и программ, 2001-2010 финансовые годы.

ПРИЛОЖЕНИЕ 2

\section{Бюджетные ассигнования США на гуманитарную помощь в сопоставлении с бюджетными ассигнованиями по программе «Мир и безопасность» для Центральной Азии в 2001-2010 финансовых годах}

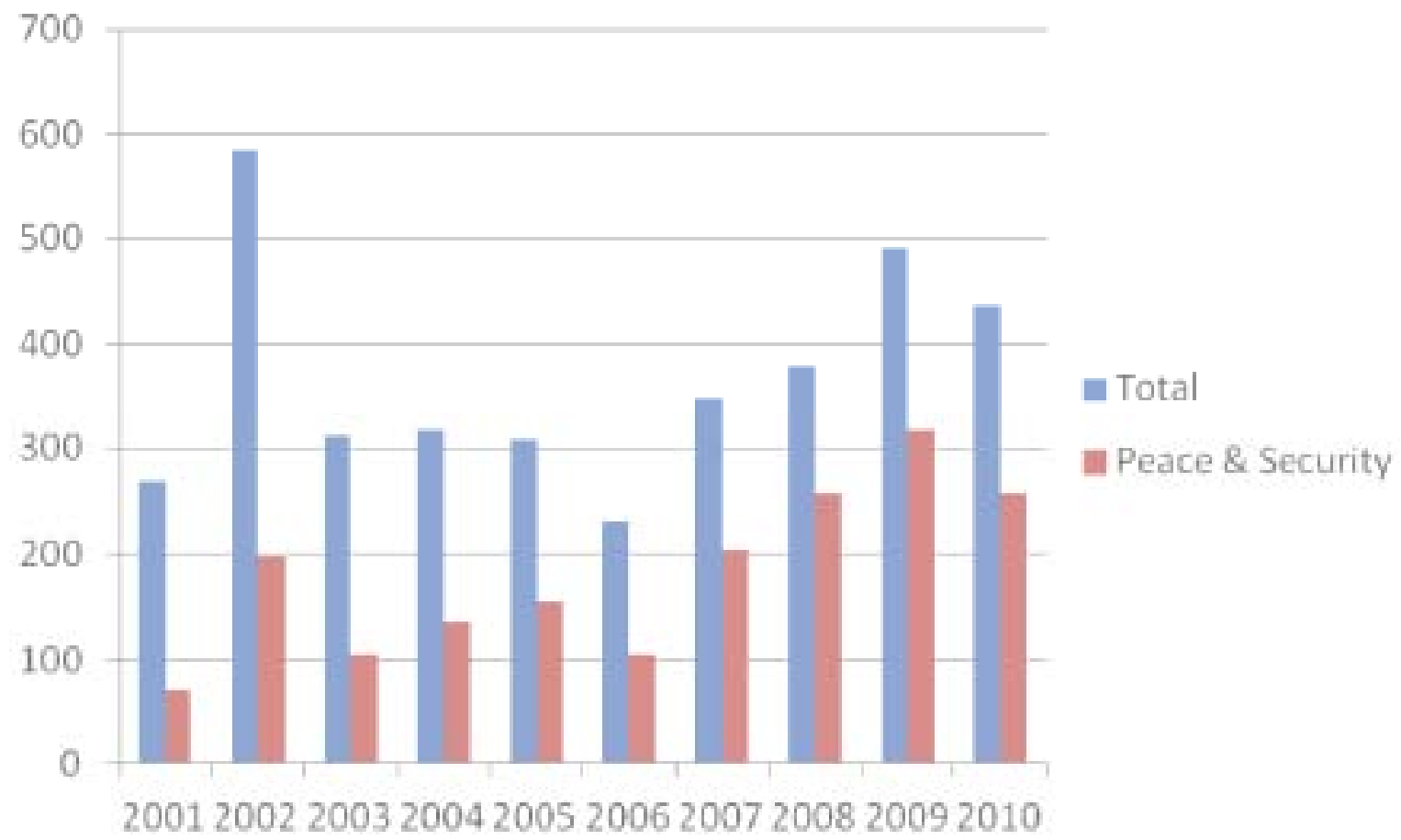

Источник: Central Asia and the Transition In Afghanistan/ A Majority Staff Report prepared for the use of the Committee on Foreign Relations United States Senate. One hundred twelfth Congress, first session. December 19, 2011. - P. 21.

Данные по общим бюджетным ассигнованиям на помощь и ассигнованиям по программам «Мир и безопасность» для Центральной Азии подготовлены в Исследовательской службе Конгресса США Джимом Найколом, специалистом по России и Евразии, специально для доклада сенатского большинства Комитету по иностранным делам Сената Конгресса США.

Примечания: помощь по программе «Мир и безопасность» включает финансирование от Министерства обороны США операций по стабилизации, вопросов безопасности, борьбы с ОМУ, наркоторговлей; финансирование от Министерства энергетики борьбы с ОМУ; финансирование от Государственного департамента программ «Во- 


\section{Региональные конфигурации международных отношений / \\ Regional configuration of international relations}

енное образование и подготовка» (IMET), «Зарубежное военное финансирование» (FMF), «Нераспространение, противодействие терроризму, разминирование и им соответствующие программы» (NADR), «Помощь Восточной Европе и Центральной Азии» (AЕЕСА) в борьбе с терроризмом, транснациональной преступностью, наркоторговлей, ОМУ, для операций по стабилизации и вопросов безопасности и для урегулирования конфликтов и примирения.

ПРИЛОЖЕНИЕ 3

Таблица 1. Общая бюджетная помощь США Центральной Азии в 2001-2010 финансовых годах

\begin{tabular}{|c|c|c|c|c|c|c|c|c|c|c|c|}
\hline & 2001 & 2002 & 2003 & 2004 & 2005 & 2006 & 2007 & 2008 & 2009 & 2010 & Всего \\
\hline Казахстан & 80,01 & 97,4 & 97,88 & 111 & 84,91 & 80,06 & 165,55 & 179,52 & 219,02 & 157,9 & 1273,25 \\
\hline Киргизстан & 43,07 & 94,47 & 53,85 & 55,25 & 55,23 & 43,34 & 71,25 & 71,23 & 111,74 & 117,53 & 716,96 \\
\hline Таджикистан & 76,48 & 136,34 & 48,71 & 53,01 & 65,69 & 42,81 & 48,44 & 67,33 & 65,6 & 82,99 & 687,4 \\
\hline Туркменистан & 12,57 & 18,93 & 10,98 & 10,42 & 18,94 & 10,44 & 19,84 & 16,83 & 20,78 & 28,25 & 167,98 \\
\hline Узбекистан & 48,33 & 224,14 & 90,77 & 84,25 & 78,28 & 49,3 & 35,9 & 38,33 & 48,55 & 37,36 & 735,21 \\
\hline Всего: & 260,46 & 571,28 & 302,19 & 313,93 & 303,05 & 225,95 & 340,98 & 373,24 & 465,69 & 424,03 & 3580,8 \\
\hline
\end{tabular}

Таблица 2. Бюджетная помощь США Центральной Азии по программе «Мир и безопасность» в 2001-2010 финансовых годах

\begin{tabular}{|c|c|c|c|c|c|c|c|c|c|c|c|}
\hline & 2001 & 2002 & 2003 & 2004 & 2005 & 2006 & 2007 & 2008 & 2009 & 2010 & Всего \\
\hline Казахстан & 36,66 & 47,63 & 51,67 & 73,75 & 56 & 50,35 & 139,8 & 155,5 & 187,6 & 137,72 & 936,68 \\
\hline Киргизстан & 6,55 & 38,62 & 11,28 & 12,33 & 17,44 & 13,27 & 18,78 & 37,57 & 42,23 & 48,62 & 246,69 \\
\hline Таджикистан & 0,75 & 21,6 & 1,62 & 7,88 & 28,99 & 10 & 17,49 & 30,48 & 25,5 & 31,48 & 175,79 \\
\hline Туркменистан & 1,87 & 7,73 & 1,16 & 0,97 & 8,98 & 2,17 & 5,72 & 5,9 & 8,71 & 13 & 56,21 \\
\hline Узбекистан & 24,27 & 82,53 & 39,18 & 41,62 & 43,43 & 28,67 & 17,82 & 26,82 & 33,98 & 25,95 & 364,27 \\
\hline Всего & 70,1 & 198,11 & 104,91 & 136,55 & 154,84 & 104,46 & 199,61 & 256,27 & 298,02 & 256,77 & 1779,64 \\
\hline
\end{tabular}

Источник: Central Asia and the Transition In Afghanistan / A Majority Staff Report prepared for the use of the Committee on Foreign Relations United States Senate. One hundred twelfth Congress, first session. December 19, 2011. P. 21. 
Бюджетные расходы СШІА на помощь государствам Центральной Азии в 2001-2010 финансовых годах

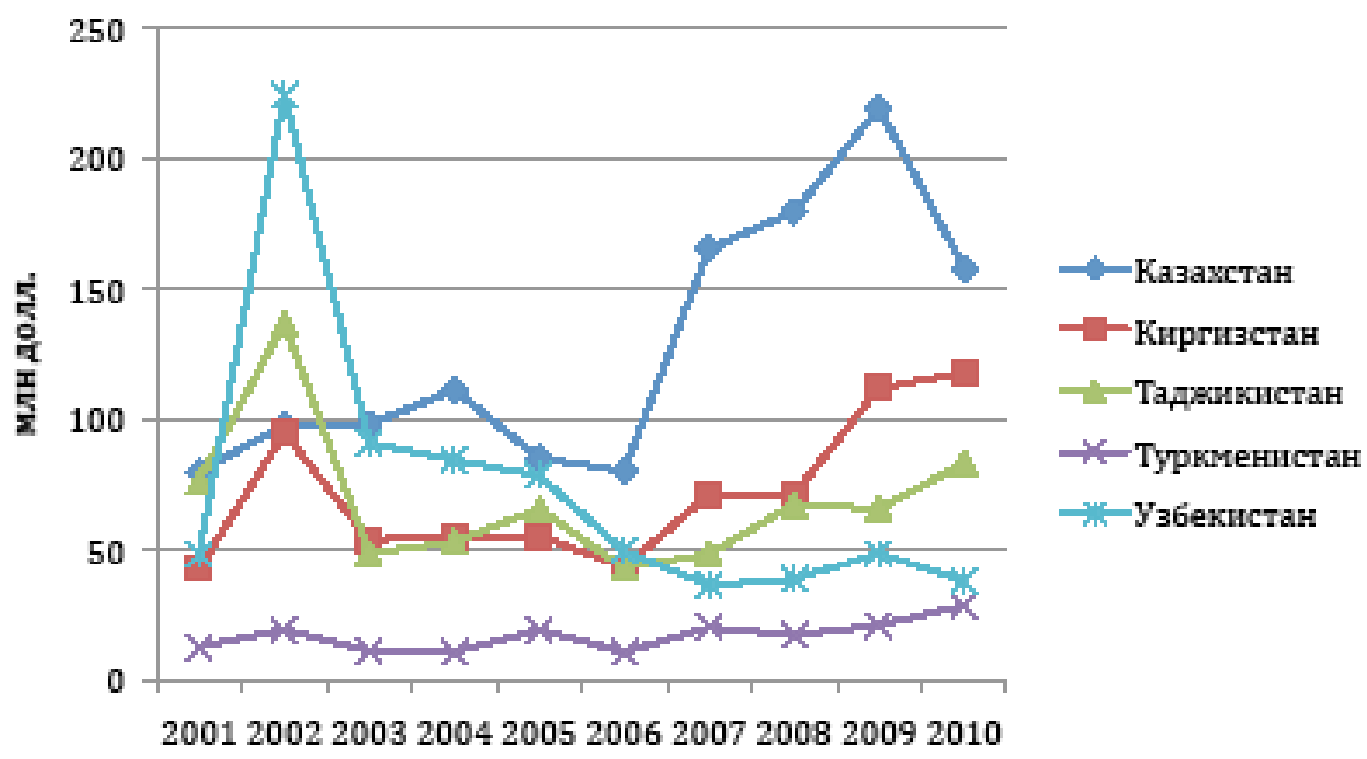

Бюджетные расходы США на помощь Центральной Азии по программе "Мир и безопасность" в 2001-2010 финансовых годах

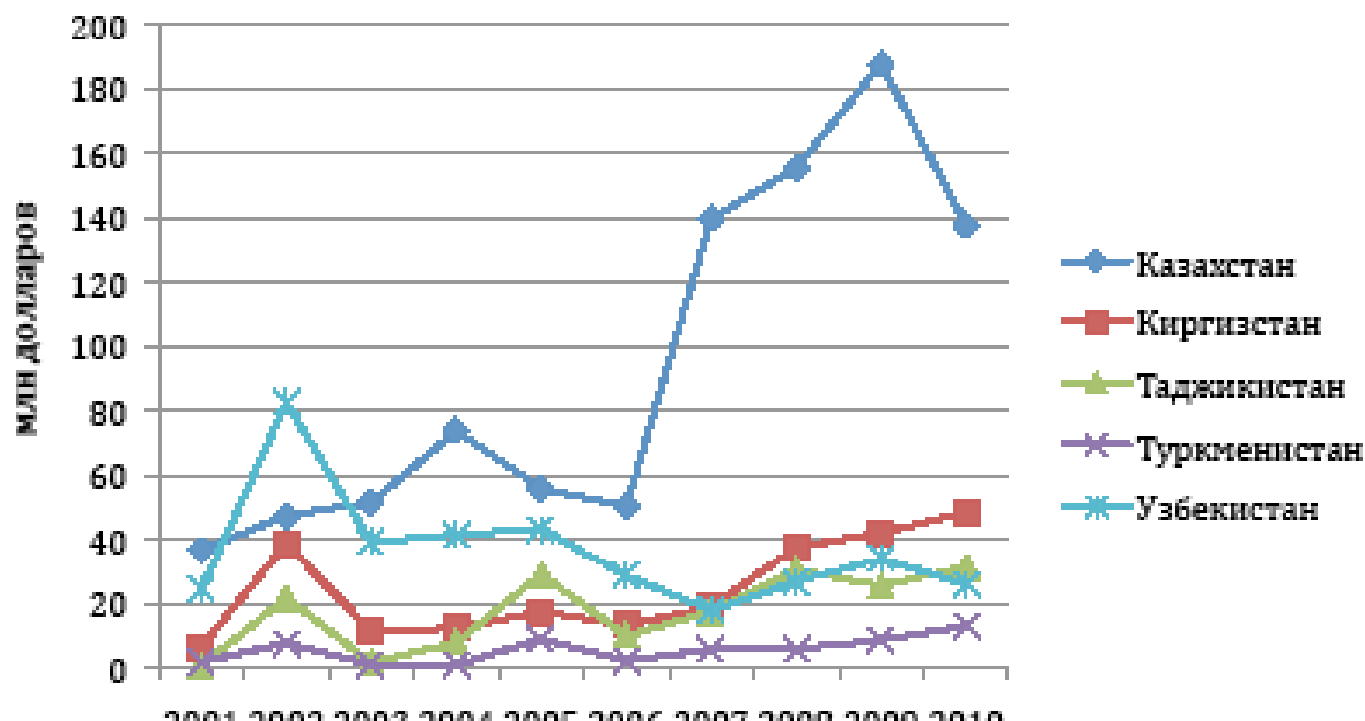

2001200220032004200520062007200820092010 
Соотношение гуманитарной и военной помощи СШІА Казахстану в 2001-2010 rT.

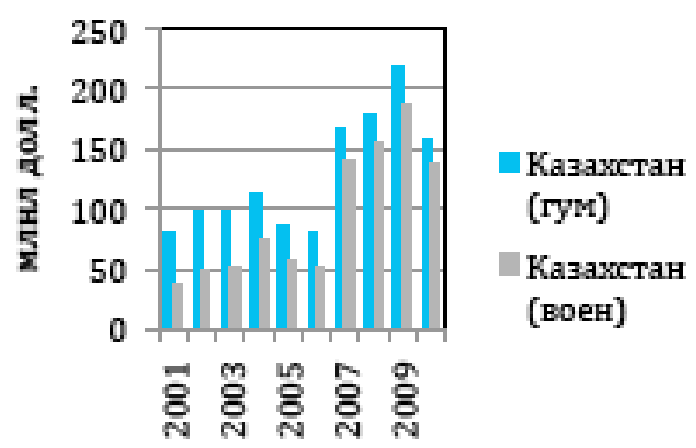

Соотношение гуманитарной и военной помощи США

Таджикистану в 2001-2010

rT.

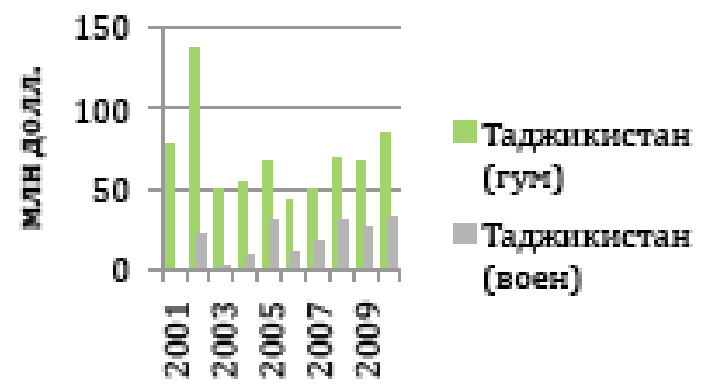

Соотношение гуманитарной и военной помощи США Киргизстану в 2001-2010

rT.

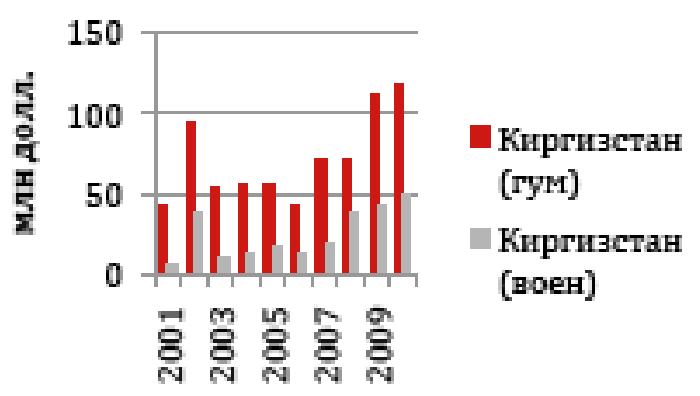

Соотношение гуманитарной и военной помощи CIIA Туркменистану в 2001-2010 гг.

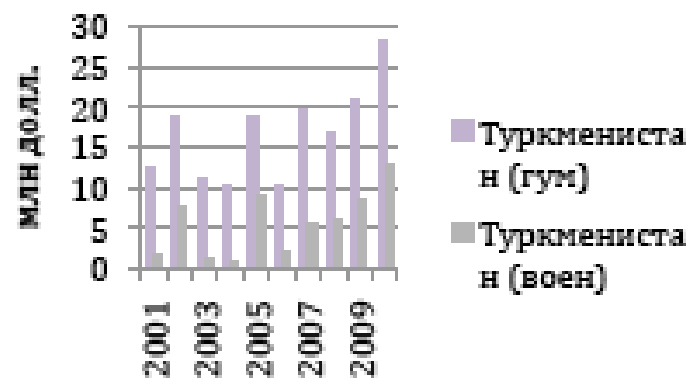

Соотношение гуманитарной и военной помощи США Узбекистану в 2001-2010 гг.

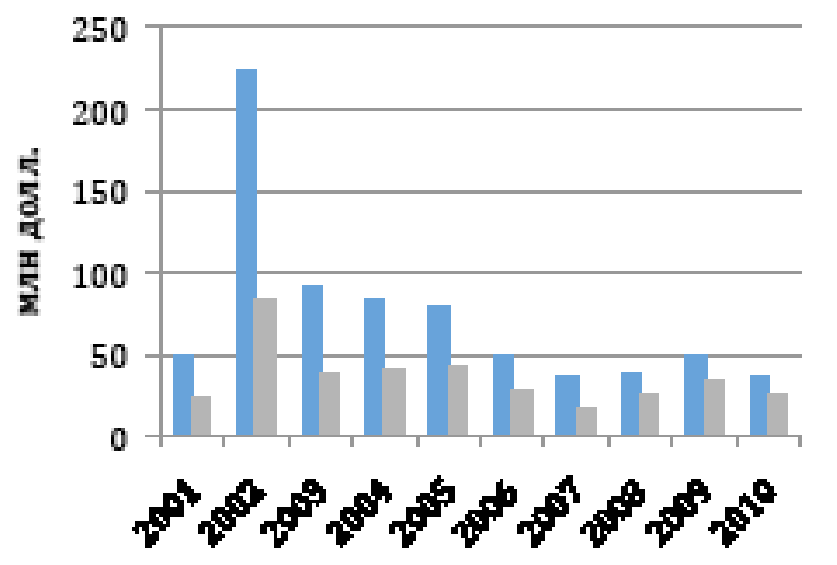

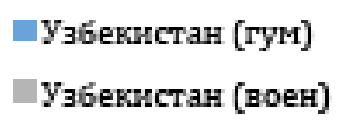

Составлено по данным приложения 3 


\section{Международные отношения International Relations}

\section{Список литературы:}

1. Yapp M. Tradition and Change in Central Asia in: Shirin Akiner (ed.). P. 1-10.

2. Ferdinand F. The New Central Asia and its Neighbours, London, Pinter Publishers. P. 1.

3. Dannreuther R. Creating New States in Central Asia // Adelphi Papers 288. International Institute for Strategic Studies. Brassey's, London. P. 42.

4. Азия и Африка сегодня. 1994. № 6. С. 24.

5. Страны мира: Энциклопедический справочник. Смоленск, 2001.

6. S. Frederick Starr, “Making Eurasia Stable,” Foreign Affairs, January/February 1996, vol. 75, no.1, pp. 80-92.

7. Zbigniew Brzezinski. The Grand Chessboard: American Primacy and its Geostrategic Imperatives, (New York: Basic Books, 1997), pp. 123-150.

8. Davis, Jacquelyn \& Sweeney, Michael. Central Asia in U.S. Strategy and Operational Planning: Where Do We Go From Here? // The Institute for Foreign Policy Analysis, Washington DC, 2004 // URL: www.ifpa.org/pdf/S-RCentral-Asia.pdf.

9. Charles Fairbanks, C. Richard Nelson, S. Frederick Starr, and Kenneth Weisbrode, Strategic Assessment of Central Eurasia, (Washington, DC: The Atlantic Council of the United States and the Central Asia and Caucasus Institute, January 2001), 131 pp., www.acus.org/Publications/Default.htm.

10. Faultlines of Conflict in the Caucasus and Central Asia: Implications for the U.S. Army, Olga Olikar and Thomas Szayna, eds., (Santa Monica, CA: RAND, 2003), 407 pp., www.rand.org/publications/MR/MR1598/index.html.

11. Vernon Loeb, "New Bases Reflect Shift in Military: Smaller Facilities Sought for Quick Strikes," Washington Post, June 9, 2003, p. A01.

12. Geoffrey Kemp, "The Persian Gulf Remains the Strategic Prize," Survival, vol. 40, no. 4, (Winter 1998-99), pp. 132-149.

13. Martha Brill Olcott, "The Caspian's False Promise," Foreign Policy, no. 111 (Summer 1998), pp. 95-112.

14. Amy Myers Jaffe and Robert Manning, "The Myth of the Caspian 'Great Game': The Real Geopolitics of Energy," Survival, vol. 40, no. 4, (Winter 1998-99), pp. 112-131.

15. Amy Myers Jaffe, Unlocking the Assets: Energy and the Future of Central Asia and the Caucasus, (Rice University: James A. Baker, III Institute for Public Policy, April 1998), 26 pp.

16. Persian Gulf Energy Fact Sheet, April 2003, www.eia.doe.gov/emeu/cabs/pgulf.html.

17. Caspian Sea: Key Oil and Gas Statistics, August 2003, www.eia.doe.gov/emeu/cabs/caspstats.html.

18. George W. Bush, Address to a Joint Session of Congress and the American People, September 20, 2001, the U.S. Capitol, Washington, DC, www.whitehouse.gov/news/releases/2001/09/20010920-8.html.

19. Paul Wolfowitz, Winning the Battle of Ideas: Another Front in the War on Terror, Georgetown Iden Lecture, Georgetown University Walsh School of Foreign Service, Washington, DC, October 30, 2003, www.defenselink.mil/ speeches/2003/sp20031030-depsecdef0642.html

20. Bernard Lewis, "The Revolt of Islam," The New Yorker, November 19, 2001, archived online at www.newyorker. com/fact/content/?011119fa_FACT2.

21. George W. Bush, Remarks by the President at the 20th Anniversary of the National Endowment for Democracy, U.S. Chamber of Commerce, Washington, DC, November 6, 2003, www.ned.org/events/anniversary/oct1603-Bush.html.

22. The Threat Posed from the Convergence of Organized Crime, Drug Trafficking, and Terrorism, Testimony by Frank Cilluffo, Deputy Director, Global Organized Crime Program, Center for Strategic and International Studies before the House Judiciary Committee, Subcommittee on Crime, December 13, 2000, www.csis.org/hill/ts001213cilluffo.html.

23. Pierre-Arnoud Chouvy, "Opiate Smuggling Routes from Afghanistan to Europe and Asia," Jane's Intelligence Review, March 2003, p. 28-31.

24. "Chapter VII: Southwest Asia," International Narcotics Strategy Report, U.S. Department of State, Bureau for International Narcotics and Law Enforcement Activities, March 2003, p. 6.

25. Chouvy, "Opiate Smuggling Routes from Afghanistan to Europe and Asia".

26. U.S. Government Assistance to and Cooperative Activities with Eurasia, "Chapter II: Country Assessments Uzbekistan," Released by the Bureau of European and Eurasian Affairs, U.S. Department of State, January 2003, available at www.state.gov/p/eur/rls/rpt/23630.htm.

27. Farida Harba, "U.S. Economic Assistance to Greatly Expand under Economic Cooperation Agreement," Eurasianet, December 10, 2001, www.eurasianet.org/departments/business/articles/eav121001.shtml.

28. Sandra I. Erwin, "War on Terrorism Tests Logisticians' Skills," National Defense Magazine, July 2002, www. nationaldefensemagazine.org/article.cfm?Id=839. 


\section{Региональные конфигурации международных отношений /}

Regional configuration of international relations

29. United States-Uzbekistan Declaration on the Strategic Partnership and Cooperation Framework, U.S. State Department Fact Sheet, March 12, 2002, www.state.gov/r/pa/prs/ps/2002/8736.htm.

30. Jackson Diehl, "Our Cold War Hangover," The Washington Post, March 18, 2002, p. A17, Lexis-Nexis.

31. Robert Wall, "MH-47 Crews Detail Conflict's Exploits, Woes," Aviation Week \& Space Technology, April 15, 2002, www.aviationnow.com/content/publication/awst/20020415/aw22.htm.

32. Military Balance 2002-2003, (London: Oxford University Press, October 2002), pp. 127-137.

33. Kenley Butler. Central Asian Military Bases. Center for Nonproliferation Studies (CNS) at the Monterey Institute of International Studies, cns.miis.edu/research/wtc01/cabases.htm.

34. "Yankees Go Home, Some Kyrgyz Say," in RFE/RL Central Asia Report, 28 February 2002, vol. 2, no. 8, compiled by Adam Albion, available at www.rferl.org/centralasia/2002/02/8-280202.asp.

35. "U.S. to use Kazakh Bases," in RFE/RL Central Asia Report, May 2, 2002, vol. 2, no. 17, compiled by Adam Albion, www.rferl.org/centralasia/2002/05/17-020502.asp.

36. Davis, Jacquelyn \& Sweeney, Michael. Central Asia in U.S. Strategy and Operational Planning: Where Do We Go From Here? P. 53.

37. Ahmed Rashid, "Safe Haven for the Taliban," Far Eastern Economic Review, October 16, 2003, pp. 19-21.

38. Anatol Lieven, "The Pressures on Pakistan," Foreign Affairs, January/February 2002, vol. 81, no. 1, p. 106, LexisNexis.

39. Ian Storey, "Indo-U.S. Strategic Ties on the Upswing," Jane's Intelligence Review, March 2003, pp. 40-43.

40. Peter Wonacott, "China Lines up Oil Deals Far Afield," Wall Street Journal, December 19, 2003, Section A, p. 13, Lexis-Nexis.

41. Antoine Blua, "Kazakhstan: Hu's Visit Highlights China's Growing Interest in Central Asia," RFE/RL Weekday Magazine, June 4, 2003, www.rferl.org/nca/features/2003/06/04062003161258.asp.

42. Годы, которые изменили Центральную Азию. - М.: ЦСПИ, 2009. — С. 191.

43. Central Asia and the Transition In Afghanistan/ A Majority Staff Report prepared for the use of the Committee on Foreign Relations United States Senate. One hundred twelfth Congress, first session. December 19, 2011. P. 4. — http://www.fdsys.gpo.gov

44. Roger N. McDermott and William D. O’Malley, “Countering Terrorism in Central Asia," Jane's Intelligence Review, October 2003, pp. 16-19.

45. Central Asia and the Transition In Afghanistan. P. 4.

46. Central Asia and the Transition In Afghanistan/ A Majority Staff Report prepared for the use of the Committee on Foreign Relations United States Senate. One hundred twelfth Congress, first session. December 19, 2011. — http:// www.fdsys.gpo.gov

47. Годы, которые изменили Центральную Азию. С. 280.

48. Mohammed Arshad. Top U.S. diplomat Nicholas Burns to retire. Reuters. 2008. Jan. 18; Pakistan's Nuclear Future: Worries Beyond War / Ed. Henry D. Sokolski. — Strategic Studies Institute, U.S. Army War College. January, 2008. P. 167-218.

49. Analysis: U.S. Aims to Edge Out Russia in Big Arms Sales to India. Reuters, Washington. 2007. Dec. 26, http://www. defensenews.com/story.php? $\mathrm{F}=3271166 \& \mathrm{C}=$ america

50. United States and India. A Shared Strategic Future / Council on Foreign Relations. Aspen Institute India. Joint Study Group Report. — Washington: Council on Foreign Relations, September, 2011. P. 4. 